\title{
Heavy minerals from Oligocene sandstones of the Menilite Formation of the Skole Nappe, SE Poland: a tool for provenance specification
}

\author{
Dorota SALATA and Alfred UCHMAN
}

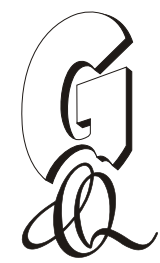

\begin{abstract}
Salata D. and Uchman A. (2012) - Heavy minerals from Oligocene sandstones of the Menilite Formation of the Skole Nappe, SE Poland: a tool for provenance specification. Geol. Quart., 56 (4): 803-820, doi: 10.7306/gq.1056

Heavy minerals from sandstones belonging mostly to the Boryslav Sandstone and Kliva Sandstone members of the lower part of the Menilite Formation (Oligocene) in the northern part of the Skole Nappe, Polish Carpathians are characterized. In the study area, the sediments were deposited in the Rzeszów and Łańcut channel zones running from the northern margin of the basin. The most frequent heavy minerals in the sandstones examined include zircon, tourmaline, rutile, staurolite, kyanite and garnet. Single grains of andalusite, sillimanite, apatite, epidote, brookite and chrome spinel occur in some samples. The very small content of apatite is related to long, continental weathering in the source area, which is referred to the Paleozoic sedimentary cover of the Małopolska Block and the easternmost part of the Upper Silesian Block. Different preservation states, morphology, degree of roundness and colour varieties suggest that the heavy minerals studied derive from various petrographic types including metamorphic, igneous and sedimentary rocks. However, the Carboniferous and Permian conglomerates and sandstones seem to be the most probable source rocks.
\end{abstract}

Dorota Salata and Alfred Uchman, Institute of Geological Sciences, Jagiellonian University, Oleandry 2a, 30-063 Kraków, Poland e-mails: dorota.salata@uj.edu.pl, alfred.uchman@uj.edu.pl (received:April 24,2012; accepted: September 11, 2012; first published online: November 9, 2012).

Key words: heavy minerals, sandstones, Oligocene, Menilite Formation, Skole Nappe.

\section{INTRODUCTION}

Analysis of heavy minerals is a powerful tool in characterizing the provenance of sedimentary material, which is an important part of facies, basin and palaeogeographic analyses. In the Polish Flysch Carpathians, this method has long been applied (e.g., Jaskólski 1931, 1939; Tokarski, 1947; Nowak and Szczurowska, 1964; Kotlarczyk, 1966; Krysowska-Iwaszkiewicz and Unrug, 1967; Wdowiarz et al., 1974; ytko et al., 1975 see Wieser and ytko, 2006; Szczurowska, 1980, 1985, 2006a, b; Leszczyński, 1981; Winkler and Slaczka, 1992, 1994; Cieszkowski et al., 1998; Salata, 2004; ytko, 2004; Oszczypko and Salata, 2005; Grzebyk and Leszczyński, 2006; and references therein), but some regions such as the northern and northeastern parts of the Skole Nappe, have been less thoroughly studied.

In this paper, we present the results of investigation of heavy minerals occurring in sandstones of the lower part of the Menilite Formation (Oligocene) in the northern part of the Skole Nappe, Polish Carpathians (Figs. 1 and 2). We characterize the content and features of heavy minerals, their possible differences between the units studied and localities, and discuss the provenance of the heavy mineral assemblages studied. The sandstones belong mostly to the Boryslav Sandstone and Kliva Sandstone members (Figs. 3-7). In the study area, they were deposited mainly in two channel zones (Rzeszów and Łańcut channel zones, respectively), identified by facies distribution (Kotlarczyk and Leśniak, 1990). The channel zones were path ways for transport of sediment from the European Platform foreland.

\section{GEOLOGICAL SETTING}

The Menilite Formation (called also the Menilite Beds) is a widespread Oligocene lithostratigraphic unit of the Outer Carpathians. Its most characteristic feature is the presence of dark, mostly black or brown shales, which accumulated on a deep, periodically anoxic sea-floor of a flysch basin (for palaeoenvironmental aspects see Kotlarczyk and Uchman, 2012). The Skole Basin was a trough bordered by the European Platform in the north and the Subsilesian ridge and slope in the 


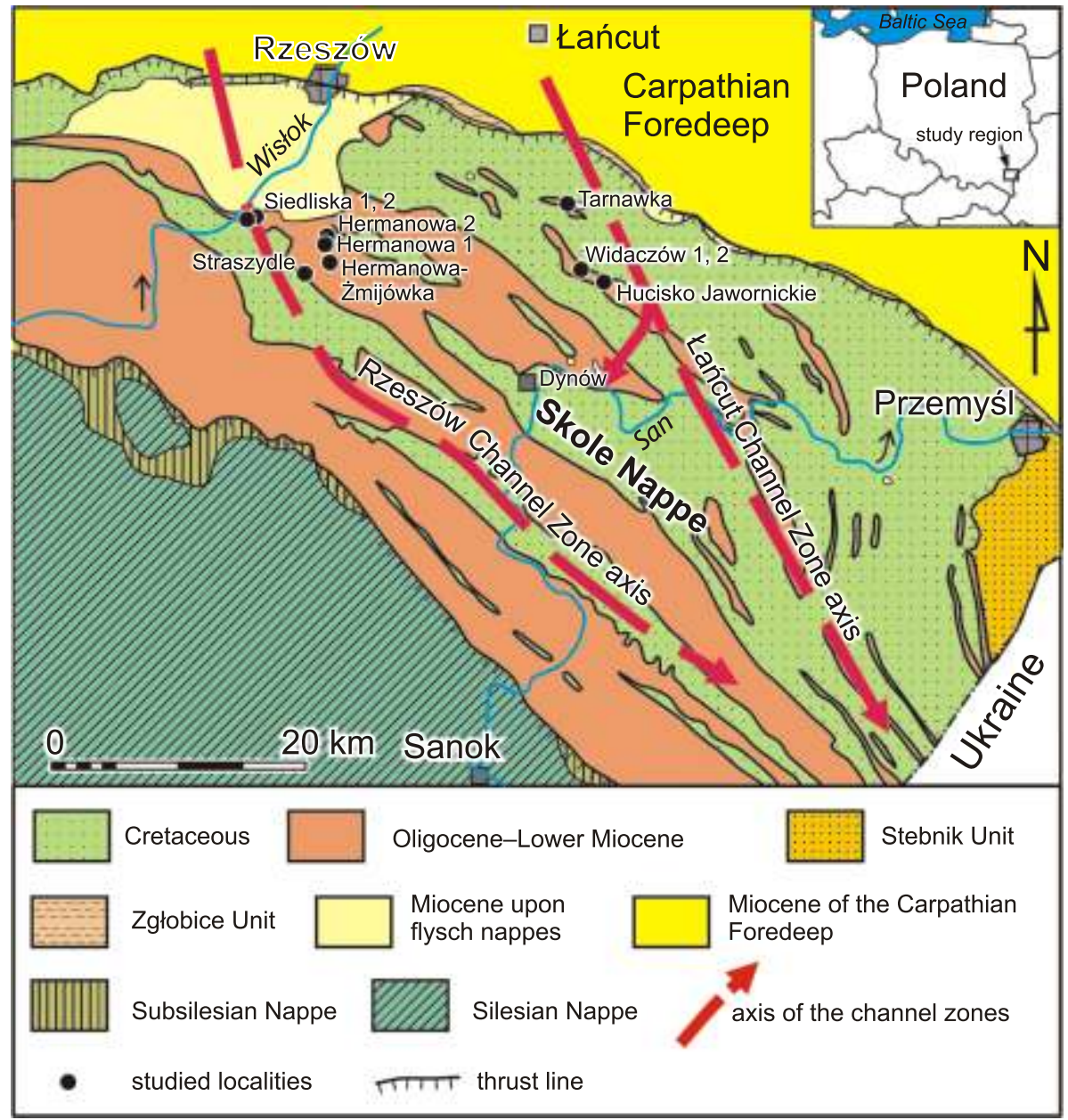

Fig. 1. Map showing location of the study area (based on Kotlarczyk and Leśniak, 1990)

\section{UNITS AND OUTCROPS STUDIED}

\section{SIEDLISKA MEMBER}

This is the lowest coarse clastic unit of the Menilite Formation, which was discovered by Friedberg (1903) and distinguished by Kropaczek (1917a, b) as the Siedliska Conglomerate. It occurs locally, mainly in the areas located to the south and south-east of Rzeszów (Ksią kiewicz et al., 1962) and Dębica (Kotlarczyk and Leśniak, 1990). It is $\sim 5-70 \mathrm{~m}$ thick, dominated by grey, thick- and mediumbedded grey conglomerates, sandstones, and calcareous mudstones interbedded with brown mudstones (Kropaczek, 1917a, b; Blaicher and Nowak, 1963; Kotlarczyk, 1985, 1991a). The deposits are rich in plant detritus and contain intraclasts and bioclasts of molluscs, nummulites, brachiopods and others (Kropaczek, 1917a, b; Pazdro, 1930; Rogala, 1932; Bieda, 1946). The deposits are interpreted as turbidites and mudflows (Rajchel, 1989; Kotlarczyk and Leśniak, 1990; Kotlarczyk, 1991a). Small foraminifers indicate their Early Oligocene age (Blaicher and Nowak, 1963). One sandstone south. The basin was at least some $150 \mathrm{~km}$ across (Gaggała et al., 2012). Its Oligocene and Lower Miocene fill is formed by the Menilite and Krosno formations, which form the highest part of the sedimentary succession of the Skole Nappe. The Menilite Formation of the Skole Nappe is a few hundred metres thick and contains sandstone units (Fig. 2). Sandstones are present in the Siedliska Member but dominate in the Boryslav Sandstone Member (lower part of the formation) and the Kliva Sandstone Member (lower-middle part of the formation), as well as in the Huwniki Sandstone and Bła owa Sandstone members in the upper part of the formation (Fig. 2). Moreover, isolated ripples and thin (rarely thick) sandstone beds occur in most of the other lithostratigraphic divisions of the formation (Fig. 2). However, the lithostratigraphic subdivision is a matter of controversy (Malata, 2006). Some thin, rippled sandstone layers of the Kliva Sandstone Member are interpreted as deposits of bottom traction currents (Unrug, 1980). The Boryslav Sandstone and Kliva Sandstone members were deposited as gravity flows, mainly in channel zones, which brought sediment from the European Platform foreland; in the study area, the Rzeszów and Łańcut channel zones were the main long-lasting corridors of sediment supply. However, the Kliva Sandstone Member also occupies large areas outside the channel zones (Kotlarczyk and Leśniak, 1990), showing that these channel zones were already filled during sedimentation of this unit. sample was studied from the $17 \mathrm{~m}$ thick stratotype section Siedliska 1 at Siedliska (Figs. 1 and 3). The sample is of brownish fine-grained sandstone rich in quartz, organic material and glauconite.

\section{BORYSLAV SANDSTONE MEMBER}

This unit (Tołwiński, 1917) is widespread in the Skole Nappe below the Kotów Chert Member of the Menilite Formation (Fig. 2). It is $20-30 \mathrm{~m}$ locally up to $40 \mathrm{~m}$ thick, composed of brown, light grey or yellowish, thick-bedded, fine- to medium-grained, non-calcareous, poorly cemented quartz sandstones interbedded with locally silicified mudstones (Tołwiński, 1917; Świdziński, 1947; Kotlarczyk and Leśniak, 1990). The sandstones are mainly quartz arenites, as in the Kliva Sandstone Member, or quartz arenites with glauconite. Their lithosoms show elongate geometries along the Rzeszów and Łańcut channel zones (Kotlarczyk and Leśniak, 1990; Kotlarczyk, 1991b). This unit was studied in the quarry at Tarnawka (Figs. 1 and 5), where it was considered previously as the Kliva Sandstone (Malata, 2006). The Hermanowa- mijówka section (Figs. 1 and 4) contains yellow sandstones and a $70 \mathrm{~cm}$ thick bed of ferruginous sandstones, which resemble the sandstones of the Boryslav Sandstone Member, but their exact stratigraphic position within the Menilite Formation is unknown. 


\section{KLIVA SANDSTONE MEMBER}

This member was studied in the Hermanowa 2 (Figs. 1 and 4), Widaczów 1 (Figs. 1 and 6), Widaczów 2 (Figs. 1 and 6), and in the Hucisko Jawornickie (Figs. 1 and 7C) sections. It is dominated by white or yellowish, poorly cemented, well-sorted, thick and very thickbedded, fine- and medium-grained quartz sandstone, mainly quartz arenites ( giet, 1963; Kotlarczyk, 1966, 1976). However, less wellsorted, coarse-grained and even conglomeratic sandstones are common (Kotlarczyk, 1966; Ślączka and Unrug, 1966). Both types contain feldspar, muscovite, glauconite, lithoclasts and small amounts of clayey, siliceous or locally calcareous cement. The quartz grains are well-rounded and dominated by quartz with undulatory extinction; frosted quartz grain surfaces (see Margolis and Kinsley, 1971) suggest aeolian reworking (Mrazec fide Macovei, 1927; Ślączka and Unrug, 1966). Sandstones contain also debrites composed of sand and pebbles of coal, black chert and quartzitic sandstone ( giet, 1963; Ślączka and Unrug, 1966).

Sandstone beds or packages of beds are separated by packages of mudstones and siltstones. Sandstone beds are commonly amalgamated ( giet, 1963) and display sharp lower and upper boundaries, graded bedding, horizontal or cross-lamination; they are poor in drag and frondescent marks, and in loading structures; locally, mudballs are present (Ślączka and Unrug, 1966; Kotlarczyk and Leśniak, 1990). They form lenticular lithosomes in transverse cross-section, which form channels within finer deposits (Unrug, 1980). The lithosomes are up to $100 \mathrm{~m}$ thick and a few kilometres wide (Kotlarczyk, 1985). The sandstones are interpreted as deposits of sand flows and turbidites ( giet, 1963; Ślączka and Unrug, 1966).

\section{OTHER UNITS AND SECTIONS}

In the Rzeszów Channel Zone, sandstones were sampled in the Straszydle, Siedliska 2 and Hermanowa 1 sections (Fig. 1). The Straszydle and Siedliska 2 sections are built predominantly of fine- to medium-grained, yellowish and quartz-dominated sandstones.

The Straszydle section (Fig. 7A) includes an abandoned quarry at Straszydle, where the Kotów Chert Member and the
Dynów Marl Member overlain by the Rudawka Tractionite Member (Fig. 2) crop out. Two samples have been collected from two sandstone beds: ST1 close to the top of the Kotów Chert Member and ST2 from a $32 \mathrm{~cm}$-thick glauconitic sandstone bed at the base of the Dynów Marl Member.

The Siedliska 2 section is in an abandoned quarry, where black shales of the Rudawka Tractionite Member crop out. Three samples were taken from three sandstone beds interbedded with the shales (Figs. 1 and 7B).

The Hermanowa 1 section (Fig. 4) is a section of an abandoned quarry, where the lower part of the Menilite Formation is exposed. Samples H1-H7 were taken from isolated sandstone beds below a thin horizon of the Dynów Marl Member, except for sample H8 which is located just above this horizon. Sandstone samples taken in the Hermanowa 1 section differ from the others in grain size and degree of sorting. They are built of silt to very fine-grained, very well-sorted quartz sand. 


\section{Siedliska 1}

N4956.538'; E2156.425'; \pm 46 m
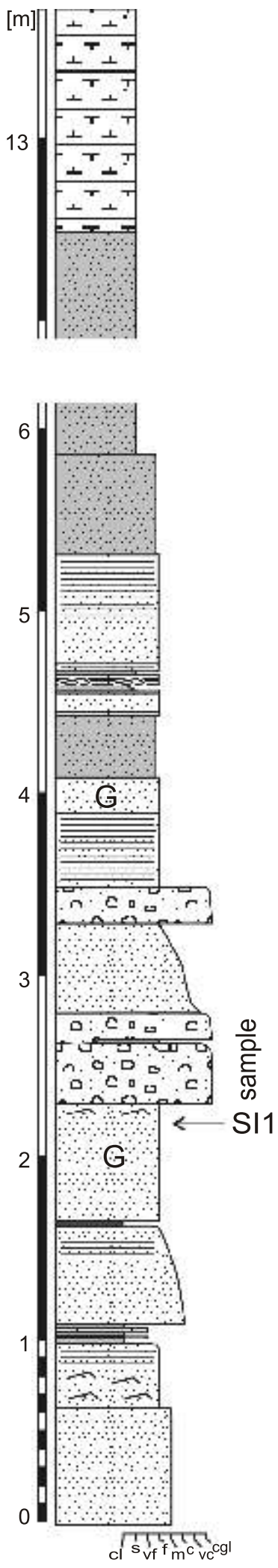

Fig. 3. Section of the Siedliska Member at Siedliska with location of the sample analysed

Grain size: $\mathrm{cl}$ - clay, $\mathrm{s}$ - silt, vf - very fine sand, $\mathrm{f}$ - fine sand, $\mathrm{m}$ - medium sand, $\mathrm{c}$ - coarse sand, vc - very coarse sand, cgl - conglomerate

\section{METHODS}

Forty-seven samples of sandstones were collected for heavy mineral analyses. Sandstones are mostly weakly or not consolidated. The consolidated sandstones were crushed and the $<0.5 \mathrm{~mm}$ fraction of the crushed material was used for further preparation. Then this fraction as well as the remaining weakly consolidated sandstone samples were cleaned of clayey material by wet sieving. After that the $63-250 \mu \mathrm{m}$ fraction was extracted by standard sieving using a mechanical shaker. The fraction extracted was washed in deionised water, disaggregated in an ultrasonic bath, divided by coning and then used for separation in heavy liquid. Sodium polytungstate of $2.9 \mathrm{~g} / \mathrm{cm}^{3}$ density was used for separation. The heavy mineral assemblages were mounted in Canada balsam and studied using standard optical techniques under a polarising microscope. For each sample, from 200 to 300 grains of transparent, non-micaceous minerals were counted according to the ribbon method (Galehouse, 1971). Mineral frequencies were calculated as volume percentages. To confirm the identification and occurrence of confusing minerals they were examined using a scanning electron microscope (SEM) Hitachi $S$-4700 equipped with an energy dispersive spectrometer (EDS) Noran Vantage working at $20 \mathrm{kV}$. The morphology and surface features of minerals were studied by means of scanning microscopy. The preliminary chemical composition of garnets and tourmalines was determined with a wave-dispersion (WDS) electron microprobe using a Cameca $S X-100$ at the Joint-Institute Analytical Complex for Minerals and Synthetic Substances at Warsaw University. The WDS analyses conditions were: $15 \mathrm{kV}$ accelerating voltage and $20 \mathrm{nA}$ beam current. Synthetic and natural mineral standards were used for analytical calibration.

\section{RESULTS}

\section{HEAVY MINERAL ASSEMBLAGES}

The most frequent heavy minerals in the samples examined include ultrastable zircon, tourmaline and rutile and moderately stable staurolite, kyanite and garnet. Single grains of andalusite, sillimanite, apatite, epidote, brookite and chrome spinel occur in some samples. Besides, very scarce (amounts far below $0.01 \%$ ) highly rounded monazite grains were found by means of scanning microscopy.

Zircon comprises $5-32 \%$ of the counted heavy minerals (Table 1 and Fig. 8) and includes several varieties that may be distinguished on the basis of degree of roundness, colour and internal features, such as zoning and inclusions. About $10 \%$ of zircons are sharp euhedral (Fig. 9A-C) or have only slightly to moderately rounded edges (Fig. 9D). The euhedral crystals are colourless, mostly with numerous inclusions (Fig. 9A, B). Around $90 \%$ of the zircon grains are highly rounded and smoothed and mostly colourless (Fig. 9E); very few were pink (Fig. 9E, F) or yellow. Some grains display internal cores (Fig. 9C) or oscillatory zoning (Fig. 9F). Individual zircons display overgrowths.

Tourmaline comprises $7-35 \%$ of the heavy fraction (Table 1 and Fig. 8) and occurs in a few varieties. Only about $10 \%$ 


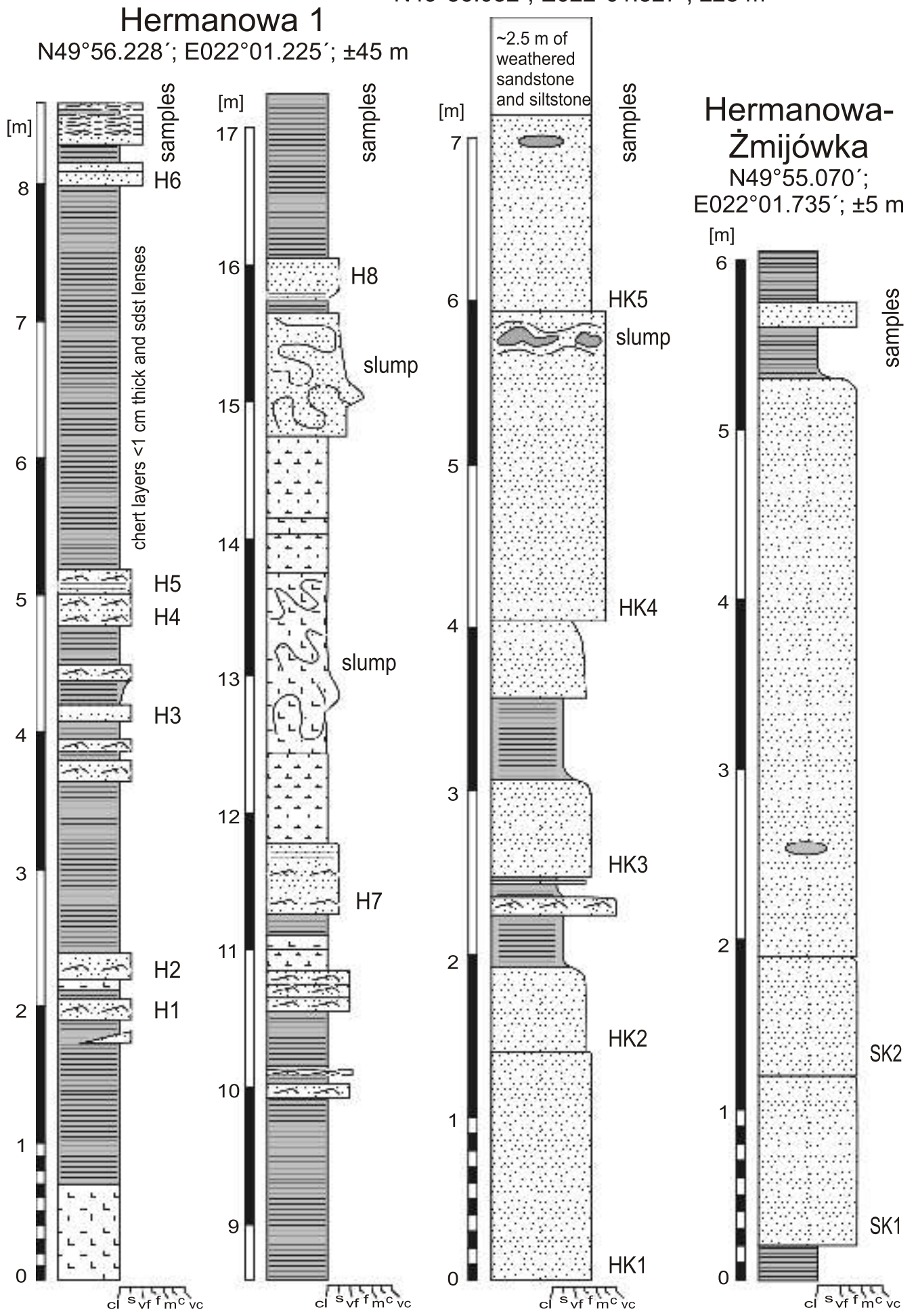

Fig. 4. Sections studied of the Rzeszów Channel Zone with location of the samples analysed 


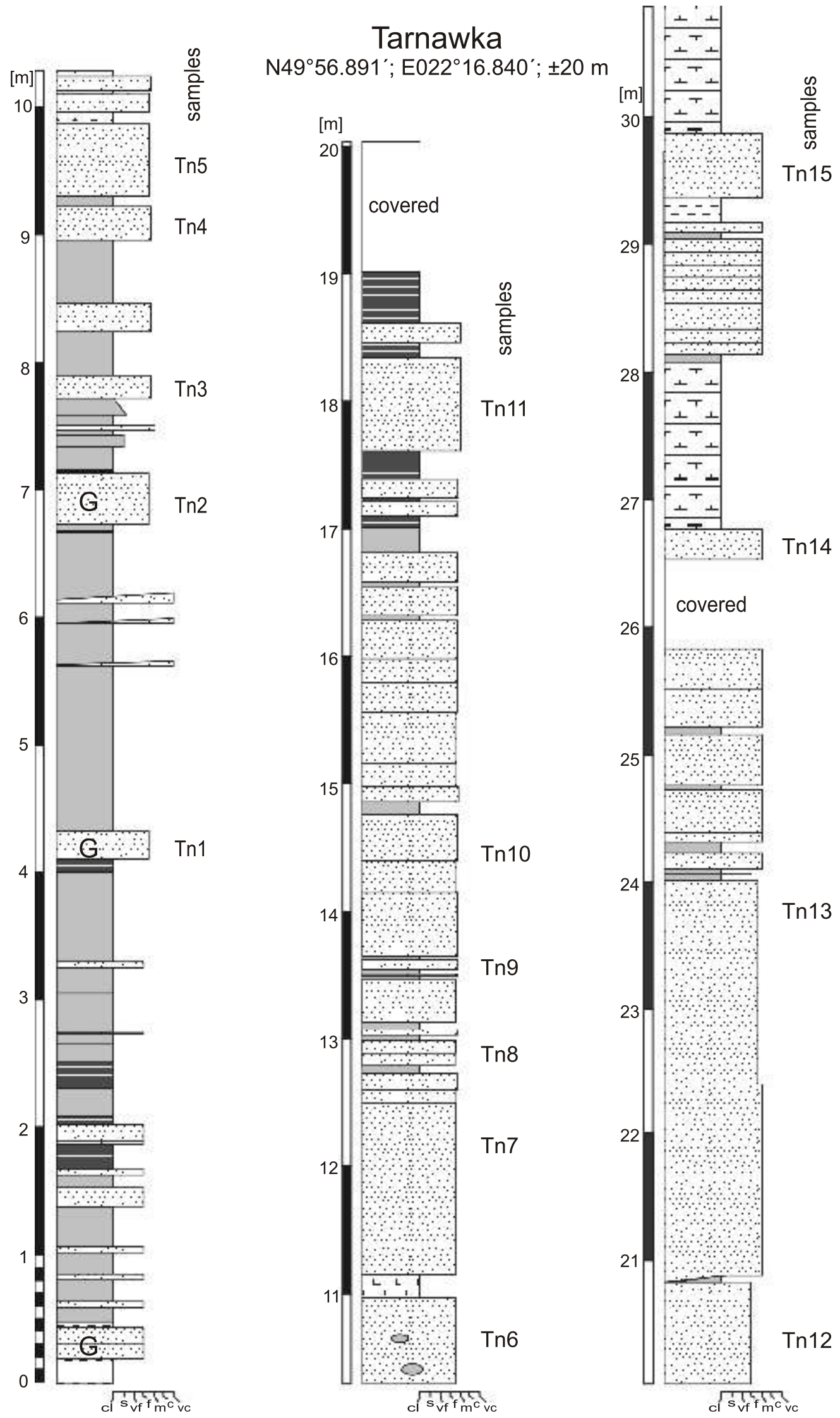

Fig. 5. Section of the lower part of the Menilite Formation in the Tarnawka Quarry with location of the samples analysed 


\section{Widaczów 2 N49 $54.122^{\prime}$ $\mathrm{E} 022^{\circ} 18.565^{\prime} ; \pm 7 \mathrm{~m}$}

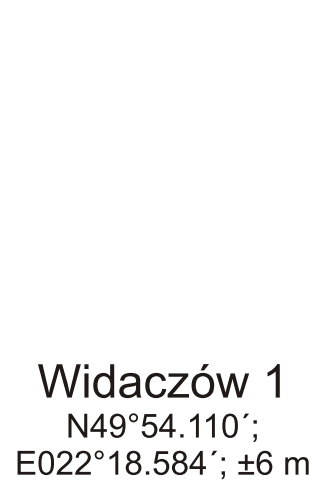

$$
\text { [m] }
$$
[m]

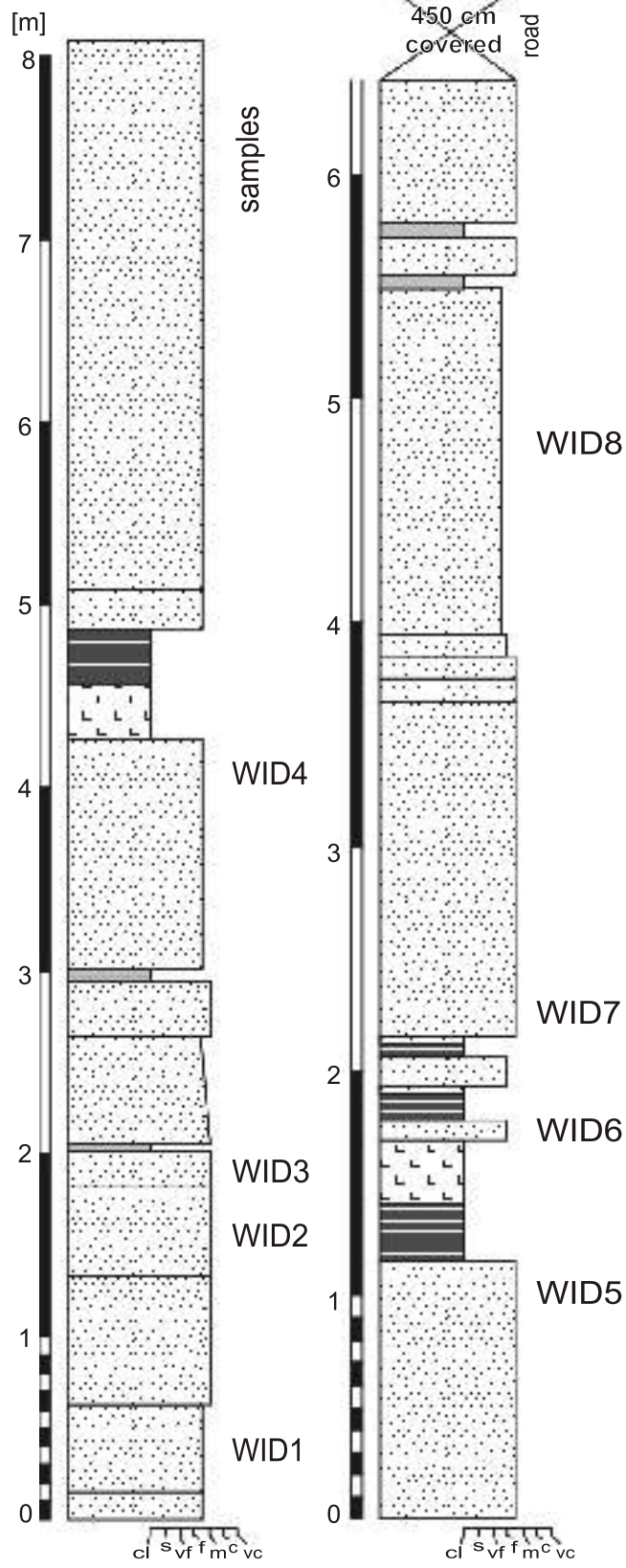

Fig. 6. Sections the Kliva Sandstone Member at Widaczów with location of the samples analysed of grains are present as sharp euhedral prisms, mostly olive-brown in colour (Fig. 9G). Highly rounded grains, often almost spherical with smooth surfaces, prevail (Fig. 9H-K). Among the rounded grains those with olive-brown pleochroic colours dominate, while individual grains are blue or pink, or display a patchy brownish-green tinge (Fig. 9G-K). Preliminary analyses of chemical composition allow the distinction of three main compositional types of tourmaline: (1) Fe-rich tourmaline (FeO over 16 wt.\%), (2) Mg-rich tourmaline ( $\mathrm{MgO}$ over 9 wt.\%) and (3) Fe-Mg tourmaline, which suggest a wide compositional spectrum of the schörl-dravite series. The tourmaline grains are also characterized by low contents of $\mathrm{Ca}$ ( $\mathrm{CaO}$ mainly below 0.5 wt.\%). Such tourmalines with $\mathrm{Fe}$ and $\mathrm{Mg}$ as dominant cations and low $\mathrm{Ca}$ contents are typical of aluminous or Al-poor metapelites and metapsammites impoverished in $\mathrm{Ca}$, while $\mathrm{Fe}$-rich ones with low $\mathrm{Ca}$ may be found in granitoids and their pegmatites (Henry and Guidotti, 1985; Henry and Dutrov, 1992). More precise chemical analyses of the tourmalines and more detailed provenance analyses of them are in preparation.

The amount of garnet ranges from $0 \%$ in very fine-grained sandstones in the Hermanowa 1 section, to $25 \%$ in the Widaczów section (Table 1 and Fig. 8). Euhedral crystals of garnets (Fig. 9L) are very rare. They occur mostly as irregular crystal fragments though highly rounded grains are also common (Fig. 9M-P). The garnets are predominantly colourless but some of the grains are pinkish, yellowish or salmon-pink in colour. Green grains occur as well. The garnets display various degrees of diagenetic corrosion manifested as small-scale facets on grain surfaces to highly etched grains, with fragile edges (Fig. 9M). The colour diversity suggests a wide compositional variety of garnets. Preliminary chemical analyses showed that most of the grains investigated represent Fe-rich almandine garnets though many include up to $40 \mathrm{~mol} \%$ of the pyrope end-member. Moreover, some grains are characterised by a significant contribution of spessartine (up to $38 \mathrm{~mol} \%$ ) and andradite + grossularite (up to $37 \mathrm{~mol} \%$ ). The green colour of some grains may indicate also the presence of $\mathrm{Cr}$-enriched varieties of garnet, although this has not yet been confirmed. The composition of the garnets suggests derivation from mainly medium grade metamorphic rocks such as gneisses, amphibolites or mica schists, contact metamorphic Ca-rich rocks and igneous bodies such as granitoids, though high grade granulites or metabasic rocks cannot be excluded (Mange and Morton, 2007 and reference therein). In order to resolve this further, detailed quantitative analyses of the garnets are in progress.

Rutile and brookite represent $\mathrm{TiO}_{2}$ polymorphs in the samples studied. Rutile dominates and constitutes $5-47 \%$ of the translucent minerals counted (Table 1 and Fig. 8). It is most abundant in samples from the Hermanowa 1 section in the Rzeszów Channel Zone (Table 1 and Fig. 8). It forms rounded or subrounded prisms, which are red or orange in colour (Fig. 9Q, R). Brookite was found only as single rounded grains in some samples (Table 1).

$\mathrm{Al}_{2} \mathrm{SiO}_{5}$ polymorphs are represented by kyanite and andalusite. The kyanite content varies from 4 to $27 \%$ of the heavy fraction, while single andalusite grains were found in a few samples (Table 1 and Fig. 8). Sillimanite usually does not exceed $0.5 \%$ (Table 1). Two different types of kyanite may be distinguished in terms of grain morphology: highly rounded almost spherical 

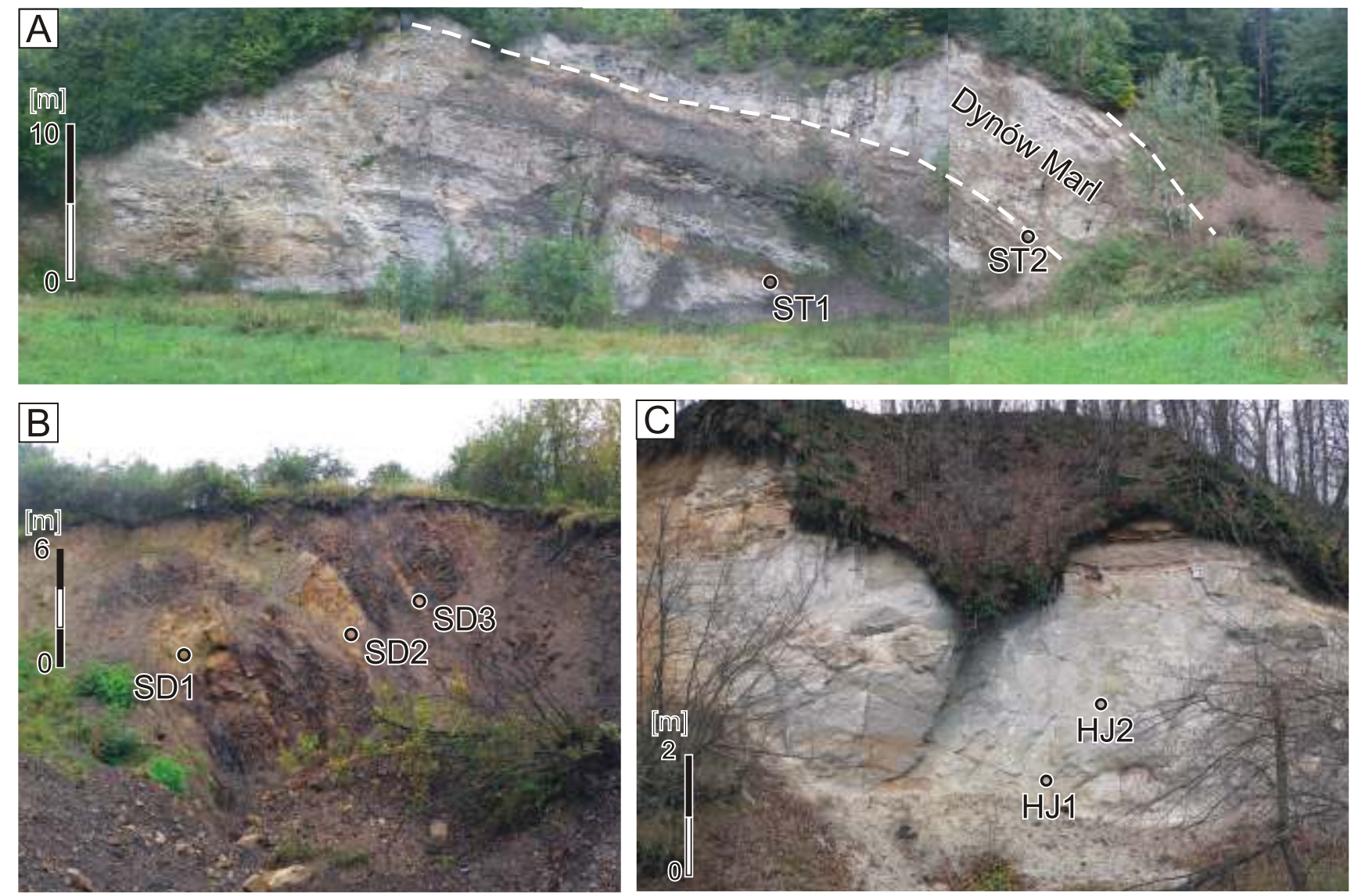

Fig. 7. Some studied exposures with location of the samples analysed

A - quarry at Straszydle; B - Siedliska 2 section; C - Kliva Member at Hucisko Jawornickie

grains and unrounded blades and prisms with easily visible cleavage (Fig. 9S, T). Kyanite is chiefly colourless but grains showing weak lavender pleochroism are also present. Andalusite is always highly rounded, up to spherical (Fig. 9U).

Staurolite constitutes $5-27 \%$ of the heavy mineral content (Table 1 and Fig. 8). It is most abundant in samples from the Tarnawka and Widaczów sections belonging to the Łańcut Channel Zone. The colour of the staurolite ranges from light yellow to almost orange. It is mostly irregular but some grains are rounded and smoothed (Fig. 9V, W). Many grains display smooth conchoidal fractures indicating mechanical destruction.

Other minerals identified in the samples include some rounded grains of epidote (Fig. 9X), scarce rounded apatite (Fig. 9Y, Z) and single grains of chrome spinel (Fig. 9Z1; Table 1 and Fig. 8). Apatite grains display corrosion surface texture indicating aggressive dissolution.

Among the heavy minerals studied, grains with hacksaw terminations, facets and etch pits visible on their surfaces may be found. Such micro-textures are visible mostly on rounded grains of garnet, kyanite, staurolite and even tourmaline (Fig. 10).

\section{DISCUSSION}

\section{POTENTIAL SOURCE AREAS}

The Outer Carpathian nappes are overthrust upon the Carpathian Foredeep, the basement being formed by flexurally subsided blocks of the European Platform. The southern edge of the platform was the northern margin of the Skole Basin in SE Poland. Now, it is deeply subducted under the nappes and probably tectonically reduced. Therefore, it is not available for direct investigation. Moreover, the Carpathians form a characteristic deep arc, which is turned significantly to the SE in the study area, suggesting tectonic rotation. Therefore, determination of the exact position of the Skole Basin in relation to the European Platform is not obvious. Judging from the subsurface maps, the northern margin of the Skole Basin in the study region can be formed by extension of the Małopolska Block and the Upper Silesian Block, which are separated by the NW-SE trending suture zone of the Kraków-Lubliniec Fault Zone (Fig. 11; Buła and Habryn, 2011).

Palaeocurrent measurements indicate two main directions into the Skole Basin during the Oligocene. According to Ksią kiewicz (1962) and Ślączka and Unrug (1966), the clastic material was transported from the NW in the southern and western parts of the Skole Basin. Kotlarczyk (1966, 1976) made palaeocurrent measurements indicating transport towards the $\mathrm{S}$ and SW from the northeastern margins of the Skole Basin in Poland. On that basis - also supported by the petrography of clasts in the Kliva Sandstone - the latter author suggested the southwestern margin of the East European Craton as the most probable general source region for the sandstones. However, later discovery of the channels zones (Kotlarczyk and Leśniak, 1990), reconstructed mainly on the basis of facies analysis, indicates transport from the northern margin of the basin towards 
Table 1

Percentages of heavy minerals (volume \%) in the sandstones investigated

\begin{tabular}{|c|c|c|c|c|c|c|c|c|c|c|c|c|}
\hline \multirow{2}{*}{$\begin{array}{c}\text { Sam- } \\
\text { ple }\end{array}$} & \multicolumn{12}{|c|}{ Mineral } \\
\hline & $\mathrm{Zr}$ & Tur & Rt & Grt & $\mathrm{Ky}$ & St & And & Ep & Ap & $\mathrm{Sp}$ & Sill & $\mathrm{Br}$ \\
\hline H1 & 12 & 25 & 43 & 0 & 16 & 4 & - & 1 & - & - & - & - \\
\hline $\mathrm{H} 2$ & 12 & 26 & 36 & 3 & 11 & 8 & - & 2 & 1 & - & - & $\mathrm{T}$ \\
\hline $\mathrm{H} 3$ & 15 & 32 & 29 & 0 & 16 & 7 & - & 1 & $\mathrm{~T}$ & - & - & - \\
\hline $\mathrm{H} 4$ & 14 & 22 & 35 & 4 & 12 & 10 & - & $\mathrm{T}$ & 1 & - & - & - \\
\hline H5 & 17 & 19 & 30 & 10 & 10 & 12 & - & $\mathrm{T}$ & $\mathrm{T}$ & - & - & - \\
\hline H6 & 18 & 17 & 35 & 0 & 15 & 12 & - & 2 & $\mathrm{~T}$ & $\mathrm{~T}$ & - & - \\
\hline $\mathrm{H} 7$ & 18 & 15 & 47 & 4 & 9 & 4 & - & 1 & 1 & - & - & - \\
\hline $\mathrm{H} 8$ & 15 & 12 & 26 & 3 & 26 & 16 & - & - & 1 & - & - & - \\
\hline HK1 & 25 & 14 & 20 & 11 & 10 & 17 & 1 & 1 & $\mathrm{~T}$ & - & - & - \\
\hline HK2 & 17 & 27 & 24 & 9 & 9 & 13 & - & - & 1 & - & - & $\mathrm{T}$ \\
\hline HK3 & 7 & 29 & 9 & 12 & 16 & 24 & 1 & 1 & $\mathrm{~T}$ & - & - & - \\
\hline HK4 & 10 & 28 & 18 & 12 & 16 & 14 & 1 & $\mathrm{~T}$ & 1 & - & $\mathrm{T}$ & - \\
\hline HK5 & 22 & 14 & 15 & 21 & 13 & 12 & $\mathrm{~T}$ & - & 1 & - & - & - \\
\hline SK1 & 26 & 22 & 21 & 5 & 12 & 14 & - & - & - & - & - & - \\
\hline SK2 & 20 & 18 & 26 & 8 & 14 & 13 & $\mathrm{~T}$ & $\mathrm{~T}$ & - & - & - & - \\
\hline SD1 & 29 & 20 & 22 & 13 & 6 & 9 & - & - & 1 & - & - & $\mathrm{T}$ \\
\hline SD2 & 26 & 12 & 29 & 19 & 5 & 8 & $\mathrm{~T}$ & - & $\mathrm{T}$ & $\mathrm{T}$ & - & $\mathrm{T}$ \\
\hline SD3 & 27 & 20 & 24 & 13 & 6 & 10 & - & - & $\mathrm{T}$ & - & - & - \\
\hline ST1 & 27 & 17 & 2 & 15 & 6 & 9 & $\mathrm{~T}$ & - & $\mathrm{T}$ & $\mathrm{T}$ & - & $\mathrm{T}$ \\
\hline ST2 & 27 & 20 & 22 & 11 & 8 & 11 & - & - & $\mathrm{T}$ & - & - & - \\
\hline Wid1 & 18 & 21 & 11 & 7 & 19 & 21 & - & 1 & 2 & - & - & - \\
\hline Wid2 & 22 & 14 & 1 & 17 & 13 & 19 & $\mathrm{~T}$ & - & - & $\mathrm{T}$ & - & - \\
\hline Wid3 & 6 & 23 & 10 & 14 & 23 & 21 & 1 & 1 & 1 & - & - & - \\
\hline Wid4 & 15 & 19 & 6 & 13 & 22 & 25 & - & $\mathrm{T}$ & - & - & - & - \\
\hline Wid5 & 10 & 25 & 11 & 10 & 19 & 25 & - & $\mathrm{T}$ & - & - & $\mathrm{T}$ & - \\
\hline Wid6 & 15 & 13 & 8 & 25 & 20 & 16 & 1 & - & $\mathrm{T}$ & $\mathrm{T}$ & $\mathrm{T}$ & - \\
\hline Wid7 & 10 & 27 & 14 & 10 & 19 & 19 & - & - & - & - & - & - \\
\hline Wid8 & 23 & 17 & 20 & 11 & 11 & 15 & - & 1 & - & $\mathrm{T}$ & - & - \\
\hline Wid9 & 17 & 20 & 12 & 10 & 20 & 21 & $\mathrm{~T}$ & $\mathrm{~T}$ & - & - & - & - \\
\hline $\operatorname{Tn} 1$ & 16 & 22 & 18 & 11 & 13 & 18 & - & 1 & 2 & 1 & - & - \\
\hline $\operatorname{Tn} 2$ & 12 & 14 & 17 & 16 & 21 & 18 & 1 & - & 2 & - & - & - \\
\hline $\operatorname{Tn} 3$ & 11 & 16 & 16 & 11 & 17 & 27 & - & $\mathrm{T}$ & 1 & - & - & - \\
\hline Tn4 & 16 & 8 & 27 & 12 & 16 & 20 & - & 1 & - & - & 1 & - \\
\hline Tn5 & 24 & 13 & 18 & 8 & 14 & 22 & - & - & 1 & - & $\mathrm{T}$ & - \\
\hline Tn6 & 18 & 13 & 12 & 18 & 18 & 19 & $\mathrm{~T}$ & - & - & - & 1 & - \\
\hline $\operatorname{Tn} 7$ & 24 & 14 & 19 & 9 & 14 & 20 & - & - & - & - & $\mathrm{T}$ & - \\
\hline Tn8 & 14 & 27 & 5 & 12 & 19 & 22 & - & 1 & - & - & - & - \\
\hline Tn9 & 14 & 21 & 7 & 14 & 21 & 24 & - & $\mathrm{T}$ & $\mathrm{T}$ & - & - & - \\
\hline $\operatorname{Tn} 10$ & 19 & 23 & 11 & 9 & 14 & 24 & - & $\mathrm{T}$ & $\mathrm{T}$ & - & - & - \\
\hline $\operatorname{Tn} 11$ & 30 & 21 & 20 & 9 & 7 & 13 & - & - & - & - & - & - \\
\hline Tn12 & 13 & 35 & 11 & 7 & 11 & 22 & - & $\mathrm{T}$ & - & - & 1 & - \\
\hline $\operatorname{Tn} 13$ & 15 & 16 & 11 & 14 & 27 & 18 & - & - & - & - & - & - \\
\hline Tn14 & 20 & 21 & 22 & 12 & 8 & 17 & - & - & - & - & - & - \\
\hline HJ1 & 17 & 23 & 6 & 9 & 15 & 26 & 2 & 1 & 1 & - & - & - \\
\hline HJ2 & 20 & 17 & 10 & 19 & 15 & 18 & 1 & - & - & - & - & $\mathrm{T}$ \\
\hline SI1 & 33 & 8 & 20 & 11 & 5 & 21 & - & - & 2 & - & - & - \\
\hline
\end{tabular}

$\mathrm{Zr}$ - zircon, Tur - tourmaline, Rt - rutile, Grt - garnet, Ky - kyanite, St staurolite, And - andalusite, Ep - epidote, Ap - apatite, Sp - chrome spinel, Sill - sillimanite, $\mathrm{Br}$ - brookite, $\mathrm{T}$ - minerals in amounts $<0.5 \%$ but $>0.1 \%$

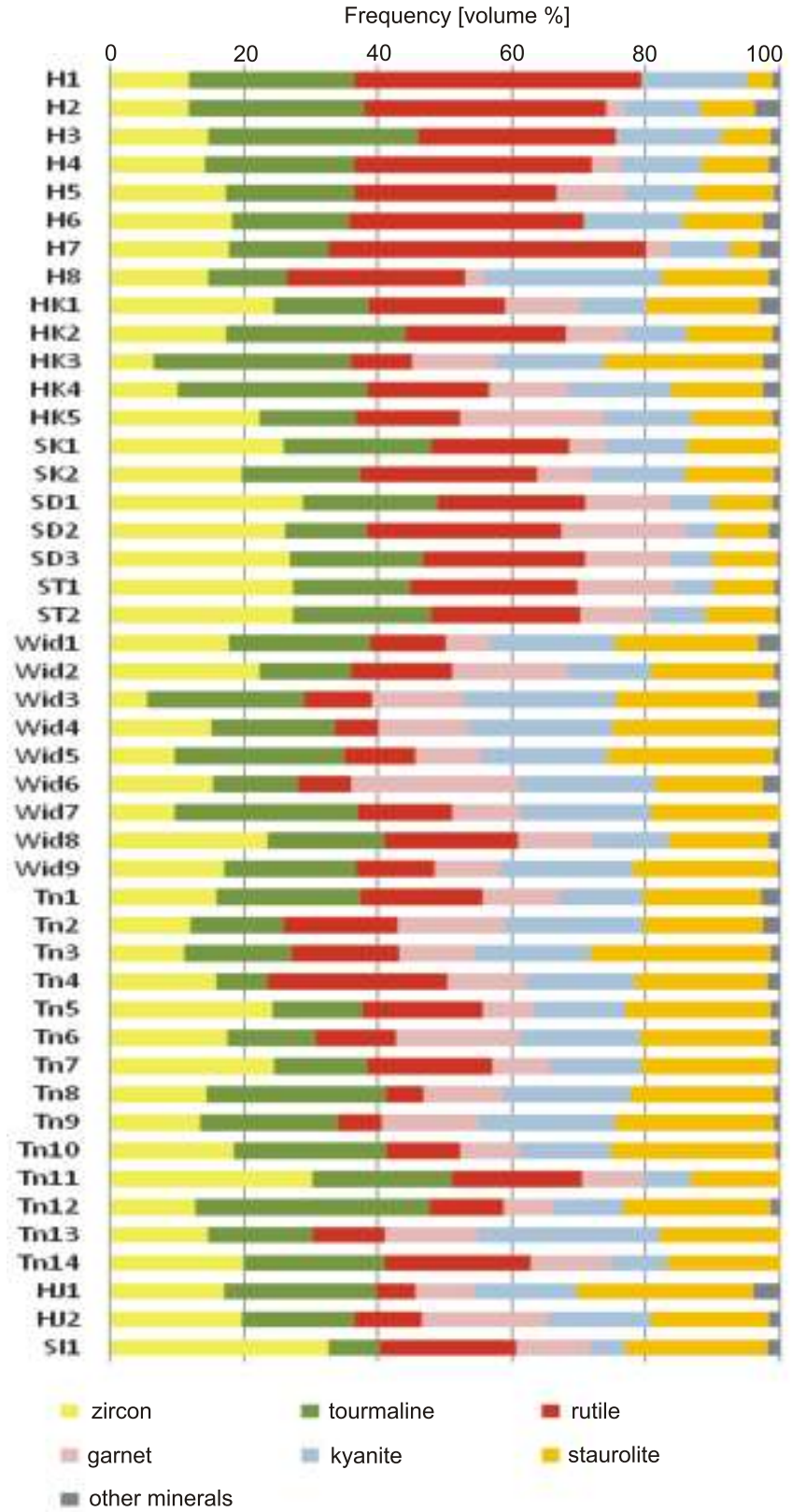

Fig. 8. Heavy mineral abundances in the Menilite Formation sandstones investigated

Other minerals include andalusite, epidote, apatite, chrome spinel, sillimanite and brookite

S and SE. This concerns the study area, especially the Rzeszów and Łańcut channel zones. Provided that the northern margin of the Skole Basin was located a few tens of kilometres to the south from the present marginal Carpathian overthrust, and making allowance for later rotation, the mouths of the two channel zones adjoin the western part of the Małopolska Block and the easternmost tip of the Upper Silesian Block (Fig. 11). Therefore, both blocks can be considered as source areas for the sandstones in the study area. Judging from the diversity and morphological features of the heavy minerals studied, their source rocks were probably mainly sedimentary rocks, such as sandstones and conglomerates with some contribution from igneous and metamorphic rock bodies. Among sedimentary 

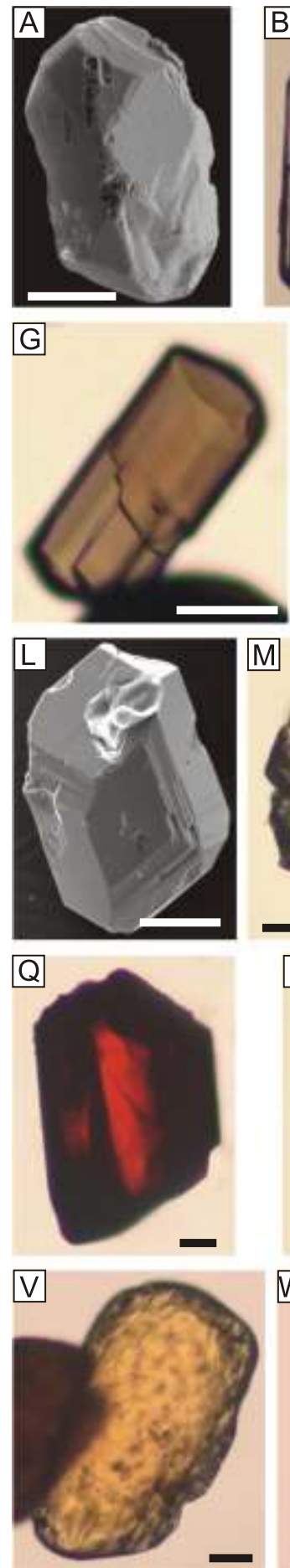
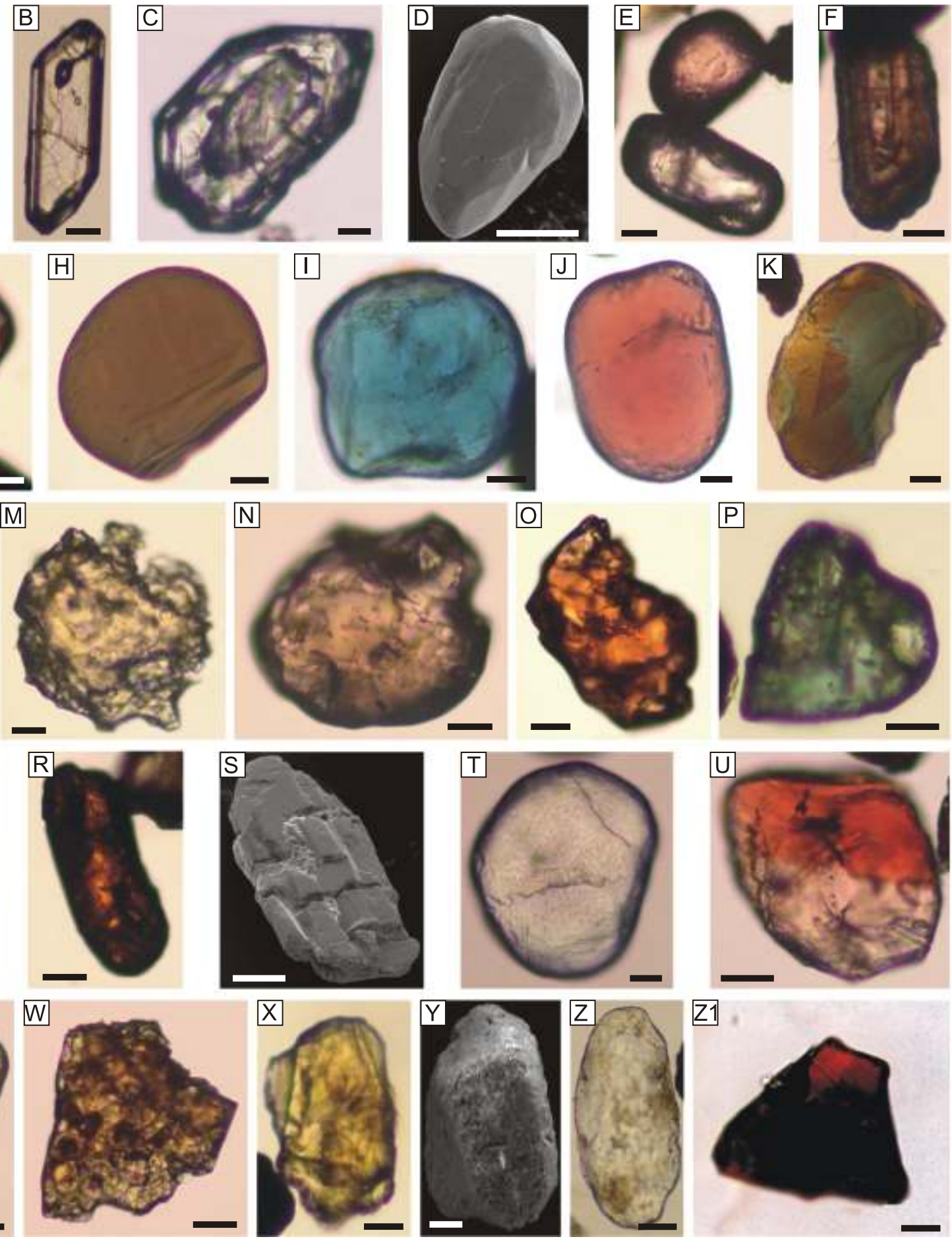

Fig. 9. Heavy mineral images from the sandstones of the lower part of the Menilite Formation

Zircon: A - euhedral, B - euhedral, colourless with numerous inclusions, C- euhedral, colourless with internal core, D - subhedral, E - rounded, pink and colourless, F-rounded, pink with oscillatory zoning; tourmaline: $\mathrm{G}$ - sharp, euhedral, olive-brown prism, H - rounded, olive-brown, I-rounded blue, J - rounded pink, $\mathrm{K}$ - rounded, patchy; garnet: $\mathrm{L}$ - euhedral, $\mathrm{M}$ - rounded salmon-pink with fragile edges, $\mathrm{N}$ - rounded pinkish, $\mathrm{O}$ - rounded, salmon-pink, $\mathrm{P}$ - rounded green; rutile: $\mathrm{Q}$ - subhedral, reddish, $\mathrm{R}$ - rounded, orange; kyanite: $\mathrm{S}$ - euhedral with well-developed cleavage, $\mathrm{T}$ - rounded, colourless; $\mathrm{U}$ rounded strongly pleochroic andalusite; staurolite: V - rounded yellow prismatic, $\mathrm{W}$ - irregular orange fragment with dissolution features; $\mathrm{X}$ - rounded greenish-yellow epidote; apatite: Y - subrounded prism, Z - rounded colourless prism with greenish-brown patches and dissolution features; Z1 subrounded red-brown chrome-spinel grain; images in colour-PPL, black and white images-SEM. The scale bar is $50 \mu \mathrm{m}$ long 

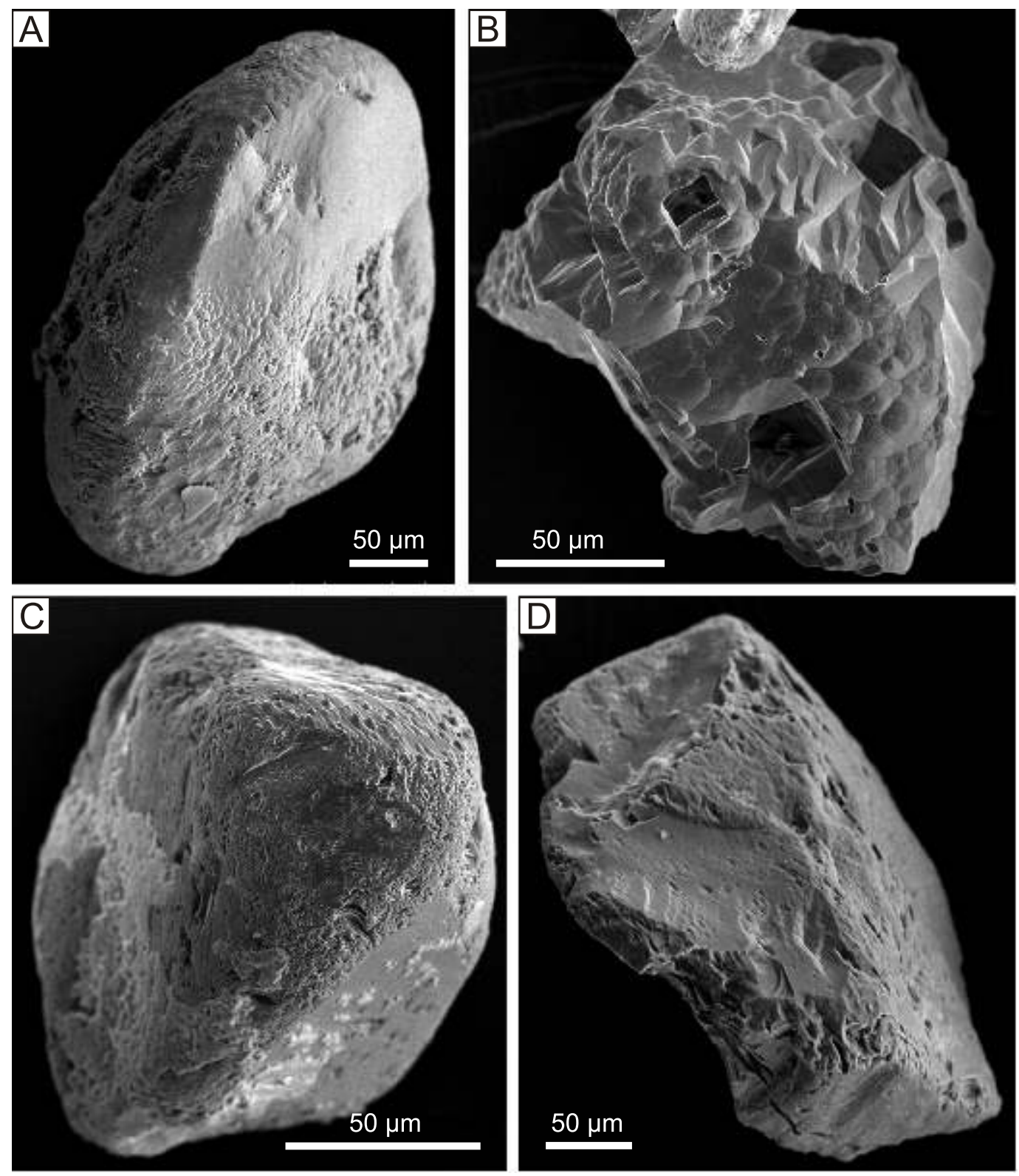

Fig. 10. Dissolution features and etch pits on heavy mineral surfaces

A - rounded tourmaline with small etch hacksaw terminations, B - garnet fragment with dissolution facets and gaps after solid inclusions, $\mathbf{C}$ - rounded kyanite with small hacksaw terminations, D - irregular fragment of staurolite with etch pits on smooth, conchoidal fractures; SEM images

sources the most prospective seem to be the Carboniferous and Permian clastic rocks, although flysch strata older than Oligocene cannot be excluded. Therefore, a brief outline of the geological successions of both of these blocks is necessary in order to consider their development and composition.

The Carboniferous transgression invaded the Małopolska Block from the north on the morphologically varied surface formed during the Bretonian Phase of the Variscan orogenic cycle; thus, the Lower Carboniferous sediments rest on various units spanning from Precambrian to Devonian (Buła, 2000; Buła and Habryn, 2011). The Carboniferous strata, preserved mainly in depressions and on slopes, represent stages from the Tournaisian to Visean and locally to the Namurian A (Jawor and
Baran, 2004). They are developed as three lithologically different successions: clastic-carbonate, carbonate and clastic (Culm) (e.g., Moryc, 1987, 1992, 1996, 2006; Jawor and Baran, 2004). The Tournaisian clastic-carbonate succession is built of rocks from shale to coarse-grained quartz arenite with intercalations of carbonate, while in the succeeding Lower Visean carbonate succession terrigenous material does not exceed a few percent. The Visean clastic strata are developed in the Culm facies as dark shales and mudstones with intercalations of sandstone. These deposits contain numerous charred plant fragments that reach considerable size (Jawor and Baran, 2004). The Upper Carboniferous deposits overlying the Culm were drilled only locally (Jawor and Baran, 2004). Upper Visean-Namurian A strata are up to 


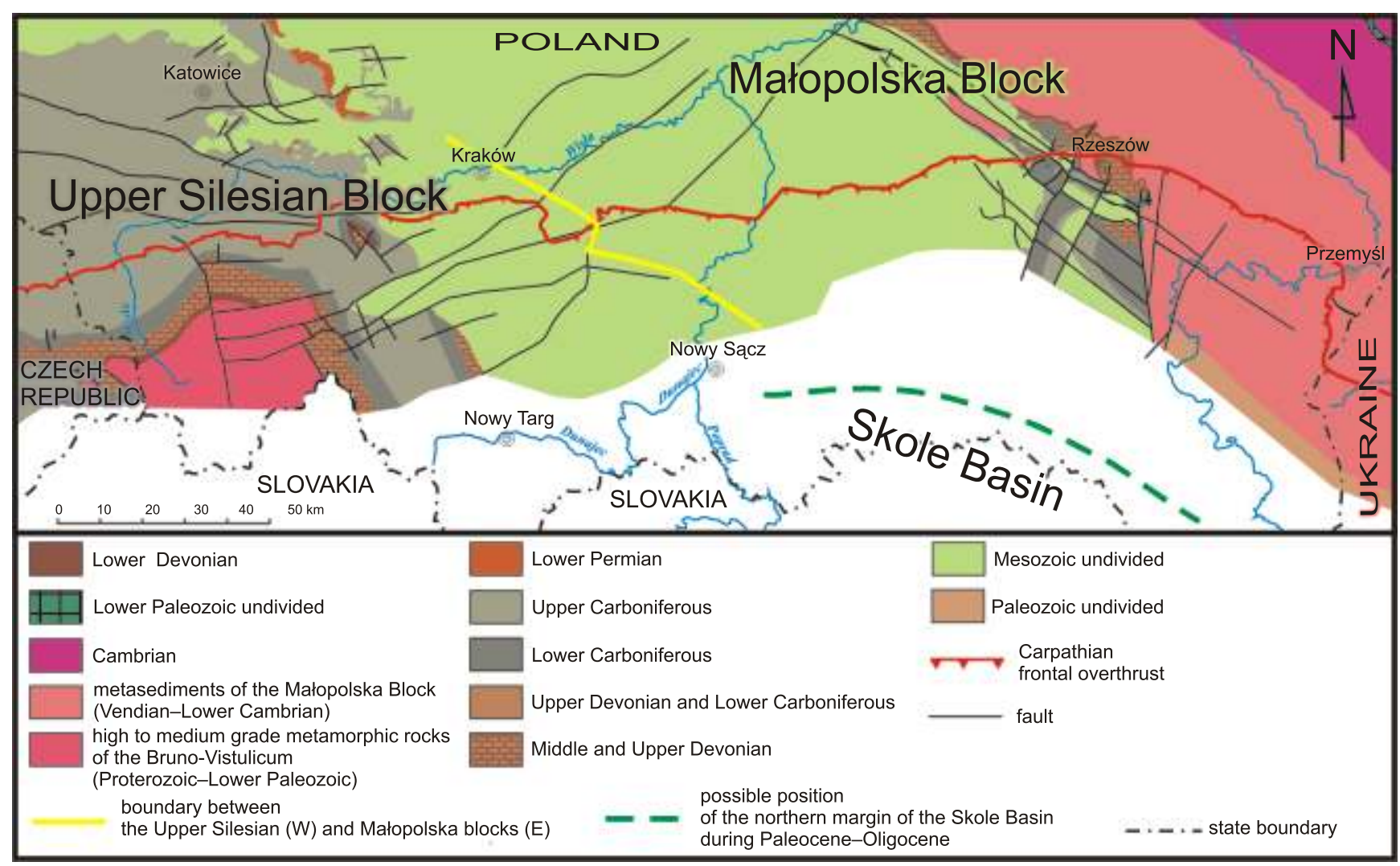

Fig. 11. Sub-Cenozoic geological structures of the Upper Silesian and Małopolska blocks and the Carpathian Foredeep with outline of the Paleocene-Oligocene position of the northern margin of the Skole Basin (based on Oszczypko and Salata, 2005 and Oszczypko et al., 2006 and references therein)

$500 \mathrm{~m}$ thick now, but according to Jawor and Baran (2004) they may have been much thicker and move widely distributed before erosion. During the new phase of transgression (Late Permian-Triassic) deposits ranging from conglomerates to shales accumulated. The Carboniferous-Permian strata of the Małopolska Block exposed to the north of the Krzeszowice graben, in the western part of the area, represent a composition similar to the Stephanian Kwaczała Arkose from the Upper Silesian Block. The main constituents of these rocks are quartz, K-feldspar, siliceous rock fragments and mica (Siedlecka and Krysowska, 1962). Further to the east of the region occur strata termed the Karniowice sandstones. Their mineral composition is also similar to the Kwaczała Arkose although the mineral proportions and features differ, indicating that they represent reworked clastic material of the arkose (Siedlecka and Krysowska, 1962).

Clastic sedimentation in the Moravian-Silesian Basin, interrupted by episodes of carbonate sedimentation, lasted mainly from the Devonian to the Permian (Unrug and Dembowski, 1971; Buła, 2000 and references therein). The Devonian-Lower Namurian A flysch sequence (Kotas, 1982) is overlain by the Carboniferous coal-bearing succession, which is subdivided into paralic and the limnic sequences (e.g., Unrug and Dembowski, 1971; Kotas, 1982; Buła and Krieger, 2004). The paralic sequence is interpreted as the sediments of a deltaic system influenced by fluvial, limnic, lagoonal and marine processes (e.g., Unrug and Dembowski, 1971; Gradziński et al., 2005). The succeeding limnic sequence is subdivided into three sedimentary units (Stopa, 1967; Dembowski 1972; Kotas, 1982): the Upper Silesian Sandstone Series (Namurian B-C), the Mudstone Series (Westphalian A-B) and the Kraków Sandstone Series (Westphalian C-D). The Upper Silesian Sandstone and the Kraków Sandstone units are composed mainly of sandstone, conglomerate and coal. Fine-grained deposits dominate in the Mudstone Series, while the coal seams are rare. The depositional environment of the limnic sequence is generally interpreted as a continental cover deposited on an alluvial plain (Unrug and Dembowski, 1971). The Mudstone Series represent the deposits of meandering rivers (Doktor and Gradziński, 1985; Gradziński et al., 2005), while the Kraków Sandstone Series is believed to have been formed on an alluvial plain by a braided river including channels and floodplains (e.g., Gradziński et al., 1995, 2005; Doktor, 2007). Clastic deposits of the paralic strata are chiefly represented by pelites and fine- to coarse-grained sandstones: compositionally lithic arenites, sublitharenites and subarkoses (Świerczewska, 1995), conglomerates and pyroclastic material. Rock pebbles found in the paralic strata are represented by metamorphic rocks such as gneisses and quartz-mica schists, granitoids and pegmatites, quartz arenites and cherts. The rock pebbles from the upper part of the limnic strata (Kraków Sandstone Series) represent generally similar proportions and types of metamorphic and sedimentary rocks but in relation to the paralic strata they include granulites and are enriched in volcanogenic pebbles (Paszkowski et al., 1995 and references therein). The Variscan sedimentary cover following the limnic sequences is represented by the Kwaczała Arkose and Permian deposits. The 
grain framework of sandstones is built mainly of quartz and K-feldspars but rock clasts occur as well (Świerczewska, 1995). Among crystalline pebbles occurring in the arkose, vein quartz, silicic plutonic and volcanic rocks as well as gneisses and mica schists are the most abundant (Turnau-Morawska and Łydka, 1954; Paszkowski et al., 1995), while in the Permian deposits various volcanic rocks, termed by Heflik and Siedlecka (1962) and Siedlecka (1964) quartz or non-quartz porphyritic rocks (rhyolites? and dacites?) and tuffs have been found.

The upper surface of the Carboniferous in the Upper Silesian Block was formed during pre-Permian (Variscan orogenesis) and especially during intense pre-Miocene (Alpine orogenesis) diastrophic movements and erosive processes (Buła and Krieger, 2004). Extensive erosion associated with these movements drastically reduced the Carboniferous strata, which are preserved mostly in depressions and on slopes of local elevations. During the early Oligocene, the Carboniferous eroded material was most probably transported to the Carpathian basins bounding the Upper Silesian and Małopolska blocks. This idea is supported by numerous findings of Carboniferous coal clasts in the Cretaceous and Paleogene deposits of the Silesian, Subsilesian and Skole flysch succession (Turnau, 1962, 1970; Kotlarczyk and Śliwowa, 1963; Kotlarczyk, 1979). The coal fragments contain Upper Carboniferous (mainly Westphalian but also Namurian) microspores and pollen known from the Upper Silesian Coal Basin and the Bug Depression as well (Turnau, 1962, 1970; Kotlarczyk and Śliwowa, 1963). They suggest that the Carboniferous coal basins extended far to the south-east of the Upper Silesian Coal Basins and may have been distributed in a broad area ranging from the Upper Silesian Coal Basin to the Bug Depression (Turnau, 1962, 1970) and situated now under the Carpathian overthrust.

Igneous bodies of Late Silurian and Carboniferous-Permian age have been drilled in boreholes in the Małopolska and Upper Silesian blocks on both sides of the Kraków-Lubliniec Fault Zone ( aba, 1999; elaźniewicz et al., 2008, and references therein). They are mainly granitoids, tephrites (basanites), trachybasalts, lamprophyres, rhyolites and dacites in the marginal part of the Małopolska Block and dacites, basalts, tephrites, lamprophyres and gabbros in the Upper Silesian Block ( aba, 1999 and references therein). Metamorphic rocks such as gneisses, amphibolites, various schists and crystalline limestones, belonging to the crystalline basement of the Upper Silesian Block, have been found in the Rzeszotary-Kraków region. They are accompanied by skarns and marbles, which are related to Carboniferous-Permian magmatism. Regionally metamorphosed rocks of the Małopolska Block are represented by the Proterozoic-?Lower Cambrian metasediments developed as phyllites or low temperature schists ( aba, 1999; elaźniewicz et al., 2008, and references therein).

The Kliva Sandstone is poor in exotic pebbles other than Upper Carboniferous coal fragments but the Babica Clay and upper part of the Ropianka Formation (called also the Inoceramian Beds) contain blocks, pebbles and grains of gneiss, mica schist and phyllite, Devonian and Carboniferous carbonate and coal, Permian volcanic and Jurassic carbonate rocks (Kotlarczyk and Śliwowa, 1963). Almost all the pebbles are rounded except for the coal fragments and metamorphic and Upper Jurassic carbonate clasts (Kotlarczyk and Śliwowa, 1963). According to these authors, the Paleocene-Late Oligocene northern margin of the Skole Basin was built mainly of Devonian and Carboniferous strata, Precambrian metamorphic rocks, which were locally overlain by Permian, Triassic-Middle Jurassic rocks and subsequent strata. Numerous boreholes reaching the northern part of the basement of the Carpathian nappes made in the 20th century seem largely to support this hypothesis.

\section{COMPARISON WITH THE EXISTING HEAVY MINERAL DATA}

Investigators dealing so far with the subject of heavy minerals from the Oligocene strata of the Skole Nappe usually published their data with reference to the Menilite Formation sandstones or the Menilite-Krosno units (Jaskólski, 1931; Tokarski, 1947; Szczurowska, 1970, 1971, 1973). The published heavy mineral analyses were mostly connected with drilling projects located in the south-eastern sector of the Polish part of the Skole Nappe (Szczurowska, 1970, 1971, 1973). Some data come from sections of the Ukrainian part of the nappe (e.g., Opir River Valley; Tokarski, 1947). However, detailed correlation of the heavy mineral percentages from the sections studied with the data in the literature is difficult or sometimes impossible, since previous investigators quoted weight percents including opaque minerals, or they did not provide information about percentages at all. In the Opir section garnet, zircon, tourmaline, rutile, staurolite, andalusite and kyanite have been found in the Menilite Formation, while apatite is not mentioned. Zircon dominates there in the heavy mineral fraction, with garnet and rutile in second and third place respectively, while tourmaline and staurolite occur in amounts of less than 10\% (Tokarski, 1947). Szczurowska (1971) mentioned that the Kliva Sandstone includes higher amounts of zircon than the sandstones in the upper part of the Menilite-Krosno Series but the description lacks detailed data. Sandstones occurring in shales of the Menilite Formation near Rudawka Rymanowska contain comparative amounts of garnet and tourmaline, slightly less zircon and minor amounts of staurolite (Jaskólski, 1931).

The source rocks of the Oligocene sandstones studied (see the chapter: Potential source areas) should be referred to mostly sedimentary rocks of the Małopolska and Upper Silesian blocks, mainly the Carboniferous and Permian clastic rocks. As noted in the previous section, they probably occupied a much larger area than today (Fig. 11), before the Oligocene and subsequent erosion. It is also possible that they were exposed extensively in the margin of the basin that is now deeply subducted under the Carpathians.

The available data on heavy minerals from the Carboniferous clastic rocks occurring in the Upper Silesian Block are scarce and refer chiefly to the Kraków Sandstone Series (Krysowska, 1959; Krysowska et al., 1960; achuń, 1996) or the Kwaczała Arkose (Turnau-Morawska and Łydka, 1954). Compiled heavy mineral data in these references show that the heavy mineral assemblages occurring in the Upper Carboniferous strata of the block consist of the same minerals as those found by us in the Menilite Formation. The similarities concern also the colour and morphology of zircon, tourmaline and garnet grains. The main difference deals with the contribution of 
apatite. The mineral is common in the Carboniferous strata of the Upper Silesian Block, reaching several percent. However, a gradual decrease in apatite was noticed in the younger beds of the Kraków Sandstone Series (Krysowska et al., 1960 and references therein). The Permian-Carboniferous clastic rocks of the Kraków region (the Kwaczała Arkose and the so called Karniowice sandstones; Łydka, 1955; Siedlecka and Krysowska, 1962) are similar in terms of heavy minerals to the corresponding strata of the neighbouring Upper Silesian Block, though a gradual decrease in less stable minerals and in apatite content may be noticed towards the eastern parts of the Kraków region (Siedlecka and Krysowska, 1962). This feature allowed Siedlecka and Krysowska (1962) to draw the conclusion that sandstones occurring in the Kraków area partially represent reworked material of the Kwaczała Arkose. The heavy mineral assemblages of the sandstones correspond well with those studied in the Menilite Formation, especially concerning their habit and optical features as well as their apatite content.

\section{HEAVY MINERAL CONSTRAINTS}

The composition of heavy mineral fractions is similar in all the samples studied, irrespective of the two channel zones represented by the sections studied. Samples representing the Łańcut Channel Zone have generally comparable frequencies of the main minerals. The percentage differences between samples do not correlate with a specific locality and are insignificant for provenance considerations. Nevertheless, elevated proportions of rutile in relation to the remaining minerals but especially in relation to garnet and, to a lesser extent staurolite, are characteristic of samples collected from the Hermanowa 1 section (H1-H8) related to the Rzeszów Channel Zone. This does not concern other samples representing the same channel zone collected in the vicinity of the Hermanowa 1 outcrop (Fig. 1). Two reasonable possibilities may explain the high rutile concentration: 1 ) there was a sudden delivery of material rich in rutile from an eroded source area and 2) the rutile concentration is a consequence of complex hydraulic processes affecting mineral settling. As the other sandstones representing the same time interval and occurring close by (see Figs. 1 and 2) do not contain so much rutile and so little garnet the first idea seems to be the least probable while the second one is worth discussion. The sandstones occurring in the Hermanowa 1 section represent silt to very fine grained, very well-sorted sand, while all the other sandstones sampled within the Rzeszów Channel Zone are medium grained and well- to moderately sorted. One of the most important factors influencing the concentration of heavy minerals in sands is their hydraulic behaviour during transport. It is strongly affected by mode of transport, sorting mechanisms as well as grain shape, density and size (e.g., Mange and Maurer, 1992; Morton and Hallsworth, 1999; Cascalho and Fradique, 2007). All these factors may distort the initial provenance signal. Rutile has a different shape and density than garnet, staurolite and the remaining minerals, thus its settling potential is different. Besides, rutile often occurs as small grains while garnet and staurolite frequently occure as large grains (Mange and Maurer, 1992). Nevertheless, the clastic material of the sandstones studied most probably underwent considerable recycling. Therefore, the high rutile concentration in the Hermanowa 1 section seems to be a combination of several factors, although as the problem concerns only the very fine-grained sandstones the grain size distribution seems to be significant.

Euhedral zircons, tourmalines and kyanite as well as locally found euhedral garnets most probably derive directly from the parent rocks and their pebbles, while the rounded grains seem to have more complex provenance. The high degree of roundness and the smooth surface of prevalent minerals suggest three possible mechanisms of their accumulation: (1) long transportat from a primary crystalline rock source in a current-swept environment, (2) multiple recycling of clastic material, i.e. origin from sedimentary sources and (3) a combination of both recycling and transport in an aqueous environment. The suite of the minerals studied is resistant to weathering and transport and may survive several cycles of erosion and sedimentation. However, staurolite, kyanite, garnet and tourmaline display surface features of dissolution, such as etch pits and hacksaw terminations (Fig. 10) which indicate that they underwent intrastratal solution during burial diagenesis. Staurolite and kyanite are stable in shallowly buried strata. Kyanite becomes unstable below $1800 \mathrm{~m}$, while staurolite disappears below 3100 m (Morton, 1984). Corrosion textures appear on their surfaces in between these depths as an effect of high-temperature pore fluid action leading consequently to dissolution (Morton, 1984; Morton and Hallsworth, 2007 and references therein). Etch pits on tourmaline surfaces may be connected with burial in sandstones containing hydrocarbons rich in $\mathrm{H}_{2} \mathrm{~S}$ (Morton and Hallsworth, 1999). Since the etch pits exist on rounded grains, it is difficult to determine unambiguously if these formed in the source area or during burial in the Skole Basin. Nevertheless, the deposits sampled are very poorly cemented, if at all, so diagenesis seems not to be advanced. Therefore, diagenetic dissolution features visible on the rounded grains appear to be inherited from source rocks than due to burial. Additionally, the fact that staurolite and kyanite are corroded yet still remain suggests limited burial depth in the source area.

The low amount, or absence, of apatite in the heavy mineral assemblages studied is striking. Three hypotheses to explaining this are possible: (1) apatite was not present in primary rocks, (2) its loss was caused by diagenetic conditions, or (3) it underwent almost complete weathering during storage periods in a source area or during deposition before final burial. A total lack of apatite in the primary rocks seems to be the least probable idea, as numerous metamorphic or igneous rocks contain this mineral (e.g., Nash, 1984; Deer et al., 1992; Chang et al., 1998). Apatite is also believed to be resistant to burial processes and rather develops secondary overgrowths than undergoes dissolution (Morton and Hallsworth, 1994, 1999; Turner and Morton, 2007). The Cretaceous and Paleogene flysch sandstones of the Magura Nappe, for example, contain significant amounts of this mineral although its host sediment underwent multiple recycling and deep burial diagenesis (Oszczypko and Salata, 2005). However, apatite is unstable in the weathering zone, especially during alluvial storage in well-vegetated humid environments, as is manifested in corrosion features on grain surfaces (e.g., Morton, 1986; Morton and Hallsworth, 1994, 1999; Turner and Morton, 2007). Moreover, apatite tends to be reduced in coastal marine environments and wholly removed 
from fluvial and deltaic sediments (Morton and Johnson, 1993; Morton and Hallsworth, 1994, 1999). The rare grains of apatite identified are rounded as are most of the other grains but like them display surface features indicating dissolution. The problem of the absence of apatite leads to the conclusion that the sedimentary material of the sandstones studied was probably transported and/or stored in a humid alluvial environment prior deposition and burial in the Skole Basin. The idea corresponds well with the depositional environment determined for the Carboniferous strata of the Upper Silesian Coal Basin (see Doktor and Gradziński, 1985; Gradziński et al., 1995; Doktor, 2007). As noted above, the first signs of apatite dissolution may be visible in the Upper Silesian Coal Basin, which presumably was a primary site of its deposition. The apatite content decreases towards younger Carboniferous strata of the basin (Krysowska et al., 1960 and references therein). Further apatite disappearance was noted to the east, in the reworked Carboniferous deposits of the Kraków area (Łydka, 1955; Siedlecka and Krysowska, 1962) and finally it is almost absent in the Menilite Formation, representing the latest site of burial.

Different preservation states, degrees of roundness and colour varieties reinforced by the preliminary chemical analyses, indicate that the heavy minerals studied might derive from various rock type. Highly rounded grains most probably derive from sedimentary rocks such as sandstones or conglomerates but they may equally derive from metasediments. The latter idea is supported by the contribution of staurolite and kyanite in the assemblages. The chemical composition of the garnets suggests mainly various medium grade but also high-grade metamorphic bodies as their parent rocks. The tourmaline chemistry points to metamorphic as well as igneous primary rocks. Rare euhedral grains of zircon and tourmaline suggest that the parent rocks were igneous and igneous/metamorphic bodies situated near to the Skole Basin. The high degree of roundness of minerals indicates water-borne transport, while the lack of apatite suggest alluvial storage before final deposition in the Skole Basin.

\section{MODE OF TRANSPORT}

Bukowy (1957) noted that Carboniferous and Upper Jurassic blocks and pebbles of low roundness from the Babica Clay (Paleocene) derived from a nearby land, while rounded pebbles were transported by a fluvial system from remote parts of the land and deposited in a foreland of the Skole Basin prior to final deposition. The coexistence of variously rounded terrigenous material was explained by its simultaneous slumping into the deeper parts of the basin (Bukowy, 1957). The Kliva Sandstone does not display features of such processes; therefore, its sand may have been transported by bottom currents (Kotlarczyk and Śliwowa, 1963). The foreland margins were initially steep, but became flattened during the Oligocene, when beaches developed and clastic material was delivered by a fluvial system from nearby land (Kotlarczyk and Śliwowa, 1963). According to Kotlarczyk (1976), the good sorting and petrographic maturity of the Kliva Sandstone at many localities can be explained by redeposition of aeolian sands, which accumulated in dunes developing in a subtropical climate on the Precambrian basement and on its sedimentary cover. These ideas correspond well with the interpretation of the absence of apatite in the heavy minerals investigated, which was probably dissolved during transportation or storage before final deposition.

\section{CONCLUSIONS}

The source area for the Oligocene sandstones of the Skole Nappe in the region of the Rzeszów and Łańcut channel zones is referred to the Paleozoic sedimentary cover (particularly the Carboniferous and Permian conglomerates and sandstones), of the Małopolska Block and partly of the Upper Silesian Block. However, the idea that the older flysch strata of the Skole Nappe and Proterozoic metasedimentary rocks also delivered clastic material to the Skole Basin cannot be excluded. The strong rounding of heavy mineral grains was formed during repeated recycling and/or in aqueous environments before final burial in the Skole Basin. Rare euhedral grains of heavy minerals derive most likely directly from primary source rocks, which may have been igneous bodies intruding into the sedimentary cover of the Małopolska and Upper Silesian blocks and associated metamorphic rocks.

Acknowledgements. We are kindly grateful to Prof. J. Rajchel, Dr. T. Malata and an anonymous reviewer for constructive comments that helped to improve the manuscript. The work was financially supported by the Jagiellonian University (DS and BW funds).

\section{REFERENCES}

BIEDA F. (1946) - La stratigraphie du Flysch des Karpates centrales polonaises basée sur les grands Foraminifères (in Polish with French summary). Ann. Soc. Geol. Pol., 16: 2-52.

BLAICHER J. and NOWAK W. (1963) - Microbiostratigraphy of the Siedliska conglomerates at Siedliska (SW of Rzeszów) (in Polish with English summary). Prz. Geol., 11 (7): 336-340.

BUKOWY S. (1957) - Sedymentacja babickich warstw egzotykowych w Karpatach Przemyskich. Ann. Soc. Geol. Pol., 26 (2): 147-155.
BUŁA Z. (2000) - The Lower Palaeozoic of Upper Silesia and West Małopolska (in Polish with English summary). Pr. Państw. Inst. Geol., 171: $1-89$.

BUŁA Z. and KRIEGER W. (2004) - Characteristics of Carboniferous strata in the southern part of the Upper Silesian block (in Polish with English summary). In: Mo liwości generowania węglowodorów w skałach karbonu w południowej części bloku górnośląskiego i małopolskiego (ed. M.J. Kotarba): 15-25. Towarzystwo Badań 
Przemian Środowiska "Geosfera”, Wydawnictwo Naukowe "Akapit", Kraków.

BUŁA Z. and HABRYN R. (2011) - Precambrian and Paleozoic basement of the Carpathian Foredeep and the adjacent Outer Carpathians (SE Poland and western Ukraine). Ann. Soc. Geol. Pol., 81: 221-239.

CASCALHO J. and FRADIQUE C. (2007) - The sources and hydraulic sorting of heavy minerals on the northern Portuguese continental margin. Develop. Sedim., 58: 75-107.

CHANG L.L.Y., HOWIE R.A. and ZUSSMAN J. (1998) - Rock-forming Minerals. Nonsilicates: Sulphates, Carbonates, Phosphates and Halides. Geological Society, London.

CIESZKOWSKI M., ZUCHIEWICZ W. and SCHNABEL W. (1998) Sedimentological and tectonic features of the Poprad Sandstone Member, Eocene, Magura Nappe: case study of the Klikuszowa quarry, Outer West Carpathians, Poland. Bull. Pol. Acad. Sc. Earth Sc., 46: $55-74$.

DEER W.A., HOWIE R.A. and ZUSSMAN J. (1992) - An Introduction to the Rock-forming Minerals. New York, John Wiley.

DEMBOWSKI Z. (1972) - General information on the Upper Silesian Coal Basin (in Polish with English summary). Pr. Inst. Geol., 61: 9-22.

DOKTOR M. (2007) - Conditions of accumulation and sedimentary architecture of the Upper Westphalian Cracow sandstone series (Upper Silesia Coal Basin, Poland). Ann. Soc. Geol. Pol., 77: 219-268.

DOKTOR M. and GRADZIŃSKI R. (1985) - Alluvial depositional environment of coal-bearing "mudstone series" (Upper Carboniferous, Upper Silesian Coal Basin) (in Polish with English summary). Studia Geol. Pol., 82: 5-67.

FRIEDBERG W. (1903) - Zagłębie mioceńskie Rzeszowa. Rozprawy Wydziału Matematyczno-Przyrodniczego Akademii Umiejętności, Serya B, 48: 219-272.

GALEHOUSE J.S. (1971) - Point counting. In: Procedures in Sedimentary Petrology (ed. R.E. Carver). Wiley Interscience, New York.

GAGAŁA Ł., VERGÉS J., SAURA E., MALATA T., RINGENBACH J.-C., WERNER P. and KRZYWIEC P. (2012) - Architecture and orogenic evolution of the northeastern Outer Carpathians from cross-section balancing and forward modeling. Tectonophysics, 532-535: 223-241

GRADZIŃSKI R., DOKTOR M and SŁOMKA T. (1995) - Depositional environments of the coal-bearing Cracow Sandstone Series (upper Westphalian), Upper Silesia, Poland. Studia Geol. Pol., 180: 149-170.

GRADZIŃSKI R., DOKTOR M and KĘDZIOR A. (2005) - Sedimentation of the coal-bearing succession in the Upper Silesia Coal Basin: research trends and the current state of knowledge (in Polish with English summary). Prz. Geol., 53 (9): 734-741.

GRZEBYK J. and LESZCZYŃSKI S. (2006) - New data on heavy minerals from the Upper Cretaceous-Paleogene flysch of the Beskid Śląski Mts. (Polish Carpathians). Geol. Quart., 50 (2): 265-280.

HEFLIK W. and SIEDLECKA A. (1962) - Petrographic characteristics of pebbles of effusive rocks occurring in Permian sediments in the vicinity of Olkusz (in Polish with English summary). Ann. Soc. Geol. Pol., 32 (1): 71-81.

HENRY D.J. and DUTROW B. (1992) - Tourmaline in a low grade clastic metasedimentary rock; an example of the petrogenetic potential of tourmaline. Contrib. Miner. Petrol., 112: 203-218.

HENRY D.J. and GUIDOTTI C.V. (1985) - Tourmaline as a petrogenetic indicator mineral: an example from the staurolite-grade metapelites of NW Maine. Am. Miner., 70: 1-15.

JASKÓLSKI S. (1931) - Materiały do geologii i petrografii fliszu karpackiego okolic Rymanowa. Spraw. Państw. Inst. Geol., 6: 697-741.

JASKÓLSKI S. (1939) - Wstęp do charakterystyki petrograficznej niektórych seryj ropnych polskich Karpat fliszowych. Biul. Państw. Inst. Geol., 23: 1-90.

JAWOR E. and BARAN U. (2004) - Geological setting and characteristics of Carboniferous strata in the southern part of the Małopolska Block (in Polish with English summary). In: Mo liwości generowania węglowodorów w skałach karbonu w południowej części bloku górnośląskiego i małopolskiego (ed. M.J. Kotarba): 25-48.
Towarzystwo Badań Przemian Środowiska "Geosfera", Wydawnictwo Naukowe "Akapit", Kraków.

KOTAS A. (1982) - Zarys budowy geologicznej Górnośląskiego Zagłębia Węglowego. Przewodnik LIV Zjazdu Polskiego Towarzystwa Geologicznego, Sosnowiec, 23-25 września: 45-72.

KOTLARCZYK J. (1966) - Diatomite horizon of the Krosno Beds in the Skole Nappe, Polish Carpathians (in Polish with English summary). Studia Geol. Pol., 19: 110-129.

KOTLARCZYK J. (1976) - Przyczynki do wyjaśnienia genezy piaskowców kliwskich w Karpatach Polskich. Spraw. Pos. Kom. Nauk. PAN, Kraków, 19 (1): 185-187.

KOTLARCZYK J. (1979) - Occurrence of coal in the Carpathian flysch some sedimentological observations (in Polish with English summary). Ann. Soc. Geol. Pol., 49 (1-2): 135-154.

KOTLARCZYK J. (1985) - An outline of the stratigraphy of marginal tectonic units of the Carpathian Orogen in the Rzeszów-Przemyśl area. In: Geotraverse Kraków-Baranów-Rzeszów-Przemyśl-Ustrzyki Dolne-Komańcza-Dukla (ed. J. Kotlarczyk): 39-63. Guide to excursion 4. Carpatho-Balkan Geological Association XIII Congress, Kraków.

KOTLARCZYK J. (1991a) - I wycieczka: poświęcona problematyce batymetrii basenu fliszowego $w$ paleogenie. In: Paleontologia i batymetria (ed. J. Kotlarczyk): 51-64. Materiały XIV Konferencji Paleontologów w Karpatach Rzeszowskich, Kamionka k. Rzeszowa, Polska, 7-9 października 1991.

KOTLARCZYK J. (1991b) - Modele basenów sedymentacyjnych jednostki skolskiej i zatoki rzeszowskiej. In: Paleontologia $i$ batymetria (ed. J. Kotlarczyk): 11-21. Materiały XIV Konferencji Paleontologów w Karpatach Rzeszowskich, Kamionka k. Rzeszowa, Polska, 7-9 października 1991.

KOTLARCZYK J. and LEŚNIAK T. (1990) - Lower part of the Menilite Formation and related Futoma Diatomite Member in the Skole Unit of the Polish Carpathians (in Polish with English summary). Wydawnictwo Akademii Górniczo-Hutniczej, Kraków.

KOTLARCZYK J. and ŚLIWOWA M. (1963) - On knowledge of the productive Carboniferous formations in the substratum of the eastern part of the Polish Carpathians (in Polish with English summary). Prz. Geol., 11 (6): 268-272.

KOTLARCZYK J. and UCHMAN A. (2012) - Integrated ichnological and ichthyological analysis of oxygenation changes in the Menilite Formation during Oligocene, Skole and Subsilesian nappes, Polish Carpathians. Palaeogeogr. Palaeoclimatol. Palaeoecol., 331-332: 104-118.

KOTLARCZYK J., JERZMAŃSKA A., ŚWIDNICKA E. and WISZNIOWSKA T. (2006) - A framework of ichthyofaunal ecostratigraphy of the Oligocene-Early Miocene strata of the Polish Outer Carpathian basin. Ann. Soc. Geol. Pol., 76: 1-111.

KROPACZEK B. (1917a) - Sprawozdanie z wycieczek geologicznych w okolicach Rzeszowa. Spraw. Kom. Fizjograf. Akad. Umiej., 51 100-105.

KROPACZEK B. (1917b) - Kleine Beiträge zur Geologie der nördlichen Karpaten Mittelgalizien (in Polish with German summary). Spraw. Kom. Fizjograf. Akad. Umiej., 51: 106-146.

KRYSOWSKA M. (1959) - Assemblages of heavy minerals in Carboniferous sediments perforated at Bolesław near Olkusz (in Polish with English summary). Kwart. Geol., 3 (4): 857-868.

KRYSOWSKA-IWASZKIEWICZ M. and UNRUG R. (1967) - Heavy minerals in the flysch of the Polish Western Carpathians. Bull. Acad. Pol. Sc., Ser. Sc. Geol. Geogr., 15 (2): 57-64.

KRYSOWSKA M., PIŁAT T. and WROCHNIAK-STOPKA W. (1960) Mineralogical-petrographical characteristic of the Sediments of the highest Carboniferous at Płaza near Chrzanów (Cracow Region) (in Polish with English summary). Kwart. Geol., 4 (2): 367-385.

KSIA K KIEWICZ M., ed. (1962) - Geological Atlas of Poland. Fascicle 13 - Cretaceous and Early Tertiary in the Polish External Carpathians. Inst. Geol., Warszawa.

LESZCZYŃSKI S. (1981) - Cię kowice Sandstones of the Silesian Unit in Polish Carpathians: a study of the coarse-clastic sedimentation in deep-water (in Polish with English summary). Ann. Soc. Geol. Pol., 51: $435-502$. 
ŁYDKA K. (1955) - Petrographic studies concerning the Permo-Carboniferous of the Cracow region (in Polish with English summary). Biul. Inst. Geol., 97: 123-215.

MACOVEI G. (1927) - Aperçu géologique sur les Carpathes Orientales. II-ème Réun. Ass. Carp. Guide des excursions, Bucureşti.

MALATA T. (2006) - Warstwy menilitowe w kamieniołomie w Tarnawce. In: Katalog obiektów geoturystycznych w Polsce (eds. T. Słomka, M. Doktor, A. Joniec and A. Kicińska-Świderska): 158-159. Wyd. Akademii Górniczo-Hutniczej, Kraków.

MANGE M. A. and MAURER H.F.W. (1992) - Heavy Minerals in Colour. Chapman and Hall, London.

MANGE M.A. and MORTON A.C. (2007) - Geochemistry of heavy minerals. Develop. Sedim., 58: 345-391.

MARGOLIS S. and KRINSLEY D. (1971) - Submicroscopic frosting on eolian and subaqueous quartz sand grains. GSA Bull., 82: 3395-3406.

MORTON A.C. (1984) - Stability of detrital heavy minerals in Tertiary sandstones of the North Sea Basin. Clay Miner., 19: 287-308.

MORTON A.C. (1986) - Dissolution of apatite in North Sea Jurassic sandstones: implications for the generation of secondary porosity. Clay Miner., 21: 711-733.

MORTON A.C. and HALLSWORTH C.R. (1994) - Identifying provenance-specific features of detrital heavy mineral assemblages in sandstones. Sedim. Geol., 90: 241-256.

MORTON A.C. and HALLSWORTH C.R (1999) - Processes controlling the composition of heavy mineral assemblages in sandstones. Sedim. Geol., 124: 3-29.

MORTON A.C. and HALLSWORTH C.R (2007) - Stability of detrital heavy minerals during burial diagenesis. Develop. Sedim., 58: 215-245.

MORTON A.C. and JOHNSSON M.J. (1993) - Factors influencing the composition of detrital heavy mineral suites in Holocene sands of the Apure River drainage basin, Venezuela. GSA Spec. Pap., 284: 171-185.

MORYC W. (1987) - Stratygrafia i rozwój facjalny dewonu i dolnego karbonu południowej części podło a zapadliska przedkarpackiego (Dyskusja). Kwart. Geol., 31 (2-3): 357-364.

MORYC W. (1992) - Geological structure of Miocene substrate formations in Sędziszów-Rzeszów region and their prospects (in Polish with English summary). Nafta-Gaz, 48: 205-223.

MORYC W. (1996) - The geological structure of Miocene substratum in Pilzno-Dębica-Sędziszów Małopolski region (in Polish with English summary). Nafta-Gaz, 52: 521-550.

MORYC W. (2006) - Budowa geologiczna podło a miocenu w rejonie Kraków-Pilzno. Cz. I. Prekambr i paleozoik (bez permu). Nafta-Gaz, 62: $197-216$

NASH W.P. (1984) - Phosphate minerals in terrestrial igneous and metamorphic rocks. In: Phosphate Minerals (eds. J.O. Nriagu and P.B. Moore). Springer-Verlag.

NOWAK W. and SZCZUROWSKA J. (1964) - Wyniki badań minerałów frakcji cię kiej oraz uwagi o paleogeografii dolnej i górnej kredy śląskiej i podśląskiej Karpat Bielskich. Kwart. Geol., 8 (4): 975-976.

OSZCZYPKO N. and SALATA D. (2005) - Provenance analyses of the Late Cretaceous - Paleocene deposits of the Magura Basin (Polish Western Carpathians) - evidence from the heavy minerals study. Acta Geol. Pol., 55 (3): 237-267.

OSZCZYPKO N., KRZYWIEC P., POPADYUK I. and PERYT T. (2006) Carpathian Foredeep Basin (Poland and Ukraine): its sedimentary, structural and geodynamic evolution. AAPG Mem., 84: 293-350.

PASZKOWSKI M., JACHOWICZ M., MICHALIK M., TELLER L., UCHMAN A. and URBANEK Z. (1995) - Composition, age and provenance of gravel - sized clasts from the Upper Carboniferous of the Upper Silesia Coal Basin. Studia Geol. Pol., 108: 45-127.

PAZDRO Z. (1930) - Les observations géologiques dans les Karpates Centrales Polonaises (Les environs de Strzy ów et Rzeszów) (in Polish with French summary). Kosmos, seria A, 55: 339-356.

RAJCHEL J. (1989) - The geological structure of the San Valley in the Dynów-Dubiecko region (in Polish with English summary). Biul. Państw. Inst. Geol., 361: 11-53.

ROGALA W. (1932) - Sprawozdanie z badań wykonanych na obszarze Karpat w latach 1930/31. Pos. Nauk. Państw. Inst. Geol., 33: 1-4.
SALATA D. (2004) - Detrital garnets from the Upper Cretaceous-Paleocene sandstones of the Polish part of the Magura Nappe and the Pieniny Klippen Belt: chemical constraints. Ann. Soc. Geol. Pol., 74 (3): 351-364.

SIEDLECKA A. (1964) - Permian in the north-eastern border of the Upper Silesia Coal Basin (in Polish with English summary). Ann. Soc. Geol. Pol., 34 (3): 309-394.

SIEDLECKA A. and KRYSOWSKA M. (1962) - Studies of origin and distribution of the Karniowice sandstones north of the Krzeszowice graben (in Polish with English summary). Ann. Soc. Geol. Pol., 32: 371-398.

STOPA S.Z. (1967) - Les problemes de subdiviosion stratigraphique du Houiller Cracovio-Silésien a la lumiere de la mégaflore (in Polish with French summary). Ann. Soc. Geol. Pol., 37: 7-39.

SZCZUROWSKA J. (1970) - Minerały cię kie w otworze wiertniczym Przysietnica IG-1. Kwart. Geol., 14 (4): 915-916.

SZCZUROWSKA J. (1971) - Wstępne badania minerałów cię kich serii menilitowo-krośnieńskiej w odwiercie Jasień IG-1. Kwart. Geol., 15 (3): 732 .

SZCZUROWSKA J. (1973) - Minerały cię kie końcowego odcinka profilu wiercenia Jasień IG 1 w Bieszczadach (cz. 2). Kwart. Geol., 17 (3): 643-644.

SZCZUROWSKA J. (1980) - Wyniki badań minerałów cię kich. Profile Głęb. Otw. Wiert. Inst. Geol., 49: 105-117.

SZCZUROWSKA J. (1985) - Minerały cię kie warstw godulskich, grodziskich, kambru dolnego. Profile Głęb. Otw. Wiert. Inst. Geol., 59: $127-131$.

SZCZUROWSKA J. (2006a) - Minerały cię kie otworu wiertniczego Borzęta IG-1. Profile Głęb. Otw. Wiert. Państw. Inst. Geol., 109: 50-51.

SZCZUROWSKA J. (2006b) - Analiza minerałów cię kich serii fliszowej. Profile Głęb. Otw. Wiert. Państw. Inst. Geol., 108: 40-41.

ŚLĄCZKA A. and UNRUG G. (1966) - Sedimentary structures and petrology of some sandstone members of the Menilite Beds, Carpathians (in Polish with English summary). Ann. Soc. Geol. Pol., 36 (2): 155-180.

ŚWIDZIŃSKI H. (1947) - Słownik stratygraficzny północnych Karpat fliszowych. Biul. Państw. Inst. Geol., 37: 1-124.

ŚWIERCZEWSKA A. (1995) - Composition and provenance of Carboniferous sandstones from the Upper Silesia Coal Basin (Poland). Studia Geol. Pol., 108: 27-43.

TOKARSKI J. (1947) - Cię kie minerały jako wskaźniki stratygraficzne serii fliszowych. Nafta, 3 (9): 261-264.

TOŁWIŃSKI K. (1917) - Przyczynek do geologii Borysławia i okolic. Czasop. Górn.-Hutn., 8: 216-217.

TURNAU E. (1962) - The age of coal fragments from the Cretaceous deposits in the Outer Carpathians, determined on microspores. Bull. Acad. Pol. Sc., Sér. Sc. géol. géogr., 10 (2): 85-89.

TURNAU E. (1970) - Plant microfossils and palaeogeography of the Carboniferous coal deposits in Polish Carpathians (in Polish with English summary). Biul. Inst. Geol., 235:163-244.

TURNAU-MORAWSKA M. and ŁYDKA K. (1954) - Petrographic study of the arkose of Kwaczała (in Polish with English summary). Ann. Soc. Geol. Pol., 22: 473-494.

TURNER G. and MORTON A.C. (2007) - The effects of burial diagenesis on detrital heavy mineral grain surface textures. Develop. Sedim., 58: 393-412.

UNRUG R. (1980) - Ancient contourites in the Menilite Beds (Oligocene) of the Carpathian Flysch, Poland. Ann. Soc. Geol. Pol., 50: 175-182.

UNRUG R. and DEMBOWSKI Z. (1971) - Diastrophic and sedimentary evolution of the Morava-Silesia Basin (in Polish with English summary). Ann. Soc. Geol. Pol., 41 (1): 119-168.

WDOWIARZ S., WIESER T., SZCZUROWSKA J., MORGIEL J. and SZOTOWA W. (1974) - Geological structure of the Skole Unit and its basement in the column of the Cisowa IG 1 borehole (in Polish with English summary). Biul. Inst. Geol., 273: 1-95.

WIESER T. and YTKO K. (2006) - Wyniki badań petrograficznych i mineralogicznych. Profile Głęb. Otw. Wiert. Państw. Inst. Geol., 107: 34-35.

WINKLER W. and SLACZKA A. (1992) - Sediment dispersal and provenance in the Silesian, Dukla and Magura flysch nappes (Outer Carpathians, Poland). Geol. Rd., 81: 371-382. 
WINKLER W. and SLACZKA A. (1994) - A Late Cretaceous to Palaeogene geodynamic model for the Western Carpathians in Poland. Geol. Carpath., 45 (2):71-82.

ABA J. (1999) - The structural evolution of Lower Palaeozoic succession in the Upper Silesia Block and Małopolska Block border zone (southern Poland) (in Polish with English summary). Pr. Państw. Inst. Geol., 166.

ACHUŃ M. (1996) - Porównanie minerałów cię kich z arenitów i egzotyków krakowskiej serii piaskowcowej. Unpubl. M.Sc. Thesis. Archive of the Institute of Geological Sciences, Jagiellonian University.
ELAŹNIEWICZ A., PAŃCZYK M., NAWROCKI J. and FANNING M. (2008) - A Carboniferous/Permian, calc-alkaline, I-type granodiorite from the Małopolska Block, Southern Poland: implications from geochemical and U-Pb zircon age data. Geol. Quart., 52 (4): 301-308.

GIET J. (1963) - Wstępna charakterystyka sedymentologiczna piaskowców kliwskich. Kwart. Geol., 7 (4): 715-716.

YTKO K. (2004) - Wyniki badań mineralogicznych i geochemicznych. Profile Głęb. Otw. Wiert. Państw. Inst. Geol., 103: 48-49. 